\title{
TEORES DE PROTEÍNA BRUTA EM DIETAS COM ALTA PROPORÇÃO DE CONCENTRADO PARA CORDEIROS CONFINADOS
}

\author{
MÁRCIA HELENA MACHADO DA ROCHA
}

Dissertação apresentada à Escola Superior de Agricultura "Luiz de Queiroz", Universidade de São Paulo, para obtenção do título de Mestre em Agronomia, Área de Concentração: Ciência Animal e Pastagens.

\author{
PIRACICABA \\ Estado de São Paulo - Brasil \\ Fevereiro - 2002
}




\title{
TEORES DE PROTEÍNA BRUTA EM DIETAS COM ALTA PROPORÇÃO DE CONCENTRADO PARA CORDEIROS CONFINADOS
}

\section{MÁRCIA HELENA MACHADO DA ROCHA}

Engenheiro Agrônomo

Orientador: Prof. Dra. IVANETE SUSIN

Dissertação apresentada à Escola Superior de Agricultura "Luiz de Queiroz", Universidade de São Paulo, para obtenção do título de Mestre em Agronomia, Área de Concentração: Ciência Animal e Pastagens.

\author{
PIRACICABA \\ Estado de São Paulo - Brasil \\ Fevereiro - 2002
}


Dados Internacionais de Catalogação na Publicação (CIP) DIVISÃO DE BIBLIOTECA E DOCUMENTAÇÃO - ESALQ/USP

Rocha, Márcia Helena Machado da

Teores de proteína bruta em dietas com alta proporção de concentrado para cordeiros confinados / Márcia Helena Machado da Rocha. - - Piracicaba, 2002.

$73 \mathrm{p}$.

Dissertação (mestrado) - - Escola Superior de Agricultura Luiz de Queiroz, 2002.

Bibliografia.

1. Concentrados protéicos para animais 2. Confinamento animal 3. Cordeiros 4. Dieta animal 5. Suplementos nitrogenados para animais I. Título

CDD 636.3085

"Permitida a cópia total ou parcial deste documento, desde que citada a fonte - $\mathrm{O}$ autor" 


\section{DEDICO}

\section{A DEUS}

Aos meus amados pais, Antônio e Marilene

Ao meu irmão, Antônio

Aos meus avós e bisavós

Aos meus amigos Jalme e Zilda

\section{OFEREÇO}

Ao meu grande amigo e companheiro, JALME DE SOUZA FERNANDES JR. 
"DEUS, nosso pai, que sois todo poder e bondade, daí força àquele que passa pela provação; daí luz àquele que procura a verdade, pondo no coração do homem a compaixão e a caridade." 


\section{AGRADECIMENTOS}

A DEUS e ao meu anjo protetor por estarem sempre ao meu lado.

À Escola Superior de Agricultura "Luiz de Queiroz" (ESALQ/USP), ao Departamento de Produção Animal e ao Clube de Práticas Zootécnicas (CPZ) pela grande contribuição para a minha formação profissional.

À Coordenação de Aperfeiçoamento de Pessoas de Nível Superior (CAPES), pela concessão de bolsa de estudo.

Ao Setor de Caprinocultura e Ovinocultura pela ajuda financeira para a realização deste projeto.

À Profa. Dra. Ivanete Susin pela excelente orientação, pela amizade,

pelos ensinamentos e, acima de tudo, por ser sempre um exemplo de vida para a minha formação profissional e pessoal.

Ao Eng. Agrônomo Jalme Jr. pela valiosa ajuda, companheirismo, incentivo e paciência principalmente nos momentos difíceis durante a condução desse trabalho.

Aos meus pais, Antônio e Marilene, e ao meu irmão, Antônio, por todo amor, apoio, incentivo e valiosa presença em todas as realizações da minha vida.

Aos meus amigos Jalme e Zilda, por todo carinho, apoio e incentivo.

Aos meus amigos Juliano José de Resende Fernandes e Reinaldo Cunha de Oliveira Jr., pela amizade e valiosa ajuda nos momentos difíceis.

Aos amigos Jozivaldo Prudêncio G. de Morais e Celso Pedroso Faria pelos valiosos ensinamentos e incentivos.

Ao Prof. Dr. Alexandre Vaz Pires, pelos ensinamentos, amizade e orientação. 
Aos Professores Vidal Pedroso Faria, Wilson Mattos e Flávio Portela pelos ensinamentos e amizade.

Aos Professores do Departamento de Produção Animal, pelos ensinamentos.

Aos funcionários Roberto, Alexandre, Edílson, Laureano, Juscelino, Antoneli e Carlos César (Laboratório de Bromatologia), pela valiosa ajuda para a realização deste projeto.

Aos colegas do curso de pós-graduação pela amizade e agradável convivência.

A todos aqueles que, direta ou indiretamente, contribuíram para a realização deste projeto. 


\section{SUMÁRIO}

Página

LISTA DE ABREVIATURAS ..............................................................

RESUMO

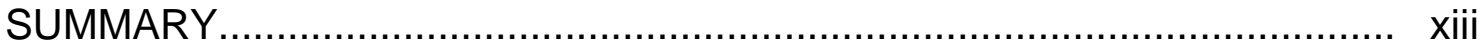

1 INTRODUÇÃO ……................................................................ 1

2 REVISÃO DE LITERATURA .............................................................. 3

2.1 Ovinos da Raça Santa Inês .......................................................... 3

2.2 Metabolismo de Nitrogênio em Ovinos ............................................... 4

2.2.1 Dinâmica do Nitrogênio Ruminal ...................................................... 5

2.2.2 Produção de Ácidos Graxos Voláteis no Rúmen ................................ 7

2.2.3 Considerações sobre Metabolismo de N pós-ruminal ......................... 9

2.3 Exigências Nutricionais de proteína .................................................. 10

2.4 Utilização de bagaço de cana-de-açúcar em dietas para ovinos ............ 14

2.5 Utilização de dietas com alta proporção de concentrado para cordeiros

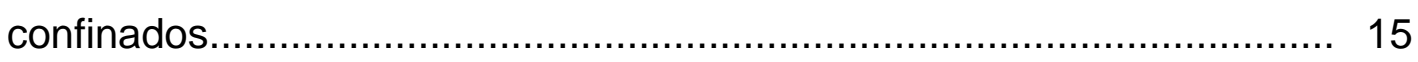

3 MATERIAL E MÉTODOS ................................................................ 17

3.1 Experimento I: Desempenho dos animais........................................ 17

3.1.1 Animais e Instalações experimentais ............................................. 17

3.1.2 Período experimental e Pesagem dos animais ................................. 18

3.1.3 Tratamentos e Fornecimento das dietas ...................................... 18

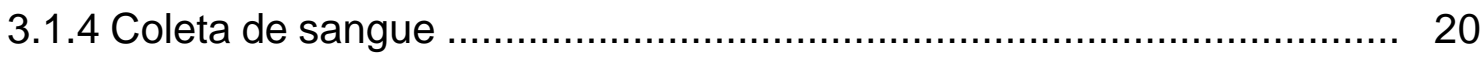

3.1.5 Abate dos animais ................................................................... 20

3.1.6 Análise estatística ................................................................... 21

3.2 Experimento II: Digestibilidade dos Nutrientes.................................... 22 
Página

3.2.1 Animais e Instalações experimentais ................................................ 22

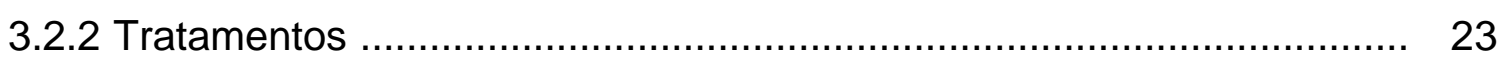

3.2.3 Período experimental ............................................................. 25

3.2.4 Coleta das amostras do alimento oferecido e recusado,fezes e

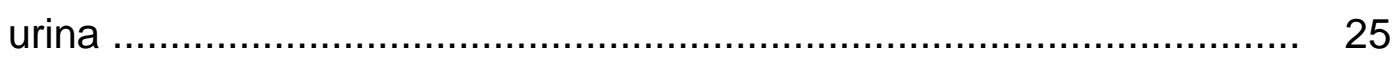

3.2.5 Coleta de fluido ruminal ......................................................... 26

3.2.6 Análise estatística ................................................................... 27

4 RESULTADOS E DISCUSSÃO ….................................................... 29

4.1 Experimento I: Desempenho dos Animais.......................................... 29

4.1.1 Ganho de peso vivo ............................................................. 29

4.1.2 Consumo de matéria seca e conversão alimentar ............................... 31

4.1.3 Consumo de proteína bruta ......................................................... 33

4.1.4 Rendimento de carcaça ............................................................ 35

4.1.5 Nitrogênio uréico plasmático (NUP) ............................................... 36

4.2 Experimento II: Digestibilidade dos Nutrientes................................... 38

4.2.1 Digestibilidade e consumo da matéria seca e matéria orgânica ........... 38

4.2.2 Digestibilidade, consumo e balanço de $\mathrm{N}$.......................................... 39

4.2.3 Digestibilidade e consumo da fibra em detergente neutro (FDN), fibra em detergente ácido (FDA) e extrato etéreo ...................................... 42

4.2.4 Parâmetros ruminais ...................................................................... 44

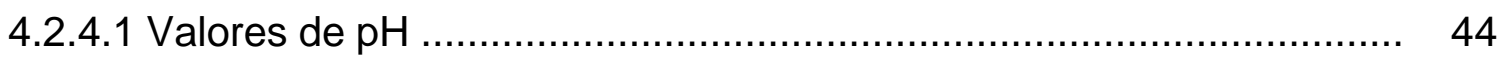

4.2.4.2 Concentração de nitrogênio amoniacal no rúmen ........................... 46

4.2.4.3 Ácidos graxos voláteis totais ......................................................... 49

4.2.4.4 Ácido acético ............................................................................. 51

4.2.4.5 Ácido propiônico ................................................................ 53

4.2.4.6 Ácido butírico ...................................................................... 55

4.2.4.7 Relação acetato/propionato .................................................. 57

4.2.4.8 Proporção molar média dos ácidos graxos voláteis no rúmen........... 59 
Página

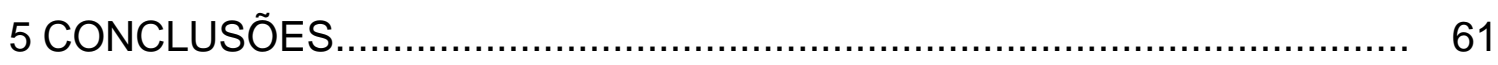

REFERÊNCIAS BIBLIOGRÁFICAS ....................................................... 62 


\section{LISTA DE ABREVIATURAS}

$\begin{array}{ll}\text { AGV } & \text { ácidos graxos voláteis } \\ \text { BIN } & \text { bagaço in natura } \\ \text { BTPV } & \text { bagaço tratado sob pressão de vapor } \\ \text { CA } & \text { conversão alimentar } \\ \text { EE } & \text { extrato etéreo } \\ \text { FDA } & \text { fibra em detergente ácido } \\ \text { FDN } & \text { fibra em detergente neutro } \\ \text { GPV } & \text { ganho de peso vivo } \\ \text { MO } & \text { matéria orgânica } \\ \text { MS } & \text { matéria seca } \\ \text { NDT } & \text { nutrientes digestíveis totais } \\ \text { NUP } & \text { nitrogênio uréico plasmático } \\ \text { PB } & \text { proteína bruta } \\ \text { PCF } & \text { peso da carcaça fria } \\ \text { PCQ } & \text { peso da carcaça quente } \\ \text { PV } & \text { peso vivo } \\ \text { PV } 0,75 & \text { peso metabólico } \\ \text { QR } & \text { quebra por resfriamento } \\ \text { RCF } & \text { rendimento da carcaça fria } \\ \text { RCQ } & \text { rendimento da carcaça quente }\end{array}$




\title{
TEORES DE PROTEÍNA BRUTA EM DIETAS COM ALTA PROPORÇÃO DE CONCENTRADO PARA CORDEIROS CONFINADOS
}

\author{
Autora: MÁRCIA HELENA MACHADO DA ROCHA \\ Orientadora: Prof. Dra. IVANETE SUSIN
}

\section{RESUMO}

Com o objetivo de avaliar a influência de teores crescentes de proteína bruta (PB) em dietas com alta proporção de concentrado para cordeiros deslanados, foram realizados dois experimentos: Experimento I (desempenho dos animais) e Experimento II (digestibilidade dos nutrientes). No Experimento I foram utilizados 48 cordeiros da raça Santa Inês (peso inicial de 18,4 $\pm 0,4 \mathrm{~kg}$ e idade média inicial de $86 \pm 2$ dias) em um delineamento experimental de blocos casualizados com 4 tratamentos e 6 repetições. As dietas experimentais continham $80 \%$ de concentrado e $20 \%$ de volumoso (10\% bagaço-de-cana hidrolisado e 10\% bagaço-de-cana in natura), com teores de 14, 16, 18 e $20 \%$ PB na matéria seca. Não houve diferença $(P>0,05)$ entre os tratamentos para consumo de matéria seca, ganho de peso, conversão alimentar e rendimento de carcaça. A concentração de $\mathrm{N}$-uréico plasmático após 3 horas do fornecimento da alimentação não aumentou para as dietas contendo teores de PB acima de $16 \%$. No Experimento II foram utilizados 5 ovinos da raça Santa Inês providos de cânulas ruminais (peso médio inicial de $43 \mathrm{~kg}$ e idade média inicial de 6 
meses) em um delineamento experimental em quadrado latino $5 \times 5$. As dietas experimentais continham $80 \%$ de concentrado e $20 \%$ de volumoso $(10 \%$ bagaço-de-cana hidrolisado e 10\% bagaço-de-cana in natura), com níveis de 12 , 14, 16, 18 e 20\% PB na matéria seca. Não houve diferença $(P>0,05)$ entre os tratamentos para digestibilidade aparente da matéria seca, da matéria orgânica, da fibra em detergente neutro, da fibra em detergente ácido e do extrato etéreo. A digestibilidade aparente da proteína bruta e a retenção de $N(\mathrm{~g} / \mathrm{dia})$ foram maiores $(P<0,05)$ para as dietas com 16, 18 e 20\% PB em relação às dietas com 12 e 14\% PB. O aumento da concentração protéica da dieta proporcionou um aumento $(P<0,05)$ na concentração de $N$ amoniacal no rúmen, entretanto não teve efeito $(P>0,05)$ nos valores de $\mathrm{pH}$ e na produção de ácidos graxos voláteis. 


\title{
CRUDE PROTEIN LEVELS FOR RAM LAMBS FED HIGH GRAIN DIETS IN FEEDLOT
}

\author{
Author: MÁRCIA HELENA MACHADO DA ROCHA
}

Adviser: Prof. Dr. IVANETE SUSIN

\section{SUMMARY}

Two experiments were conducted to evaluate the effects of crude protein (CP) levels on high grain diets fed to ram lambs. In Exp. I (performance trial), 48 Santa Inês lambs (initial body weight $18.4 \pm 0.4 \mathrm{~kg}$ and $86 \pm 2$ days old) were fed 4 experimental diets containing 14,16, 18 and 20\% CP, in a completely randomized block desing. Diets consisted of $80 \%$ concentrate and $20 \%$ sugarcane bagasse. There were no differences $(P>0.05)$ in dry matter intake, average daily gain, feed efficiency and dressing percentage. Plasma urea nitrogen concentration did not increase in diets containing more than $16 \% \mathrm{CP}$. In Exp. II (metabolism trial), 5 Santa Inês lambs (43 kg body weigh) fitted with ruminal cannulas were used in a $5 \times 5$ Latin Square design. Diets consisted of $80 \%$ concentrate and $20 \%$ sugarcane bagasse with $12,14,16,18$ and $20 \%$ CP. 
There were no differences $(P>0.05)$ in dry matter, organic matter, neutral detergent fiber, acid detergent fiber and ether extract apparent digestibilities in the total digestive tract. Crude protein apparent digestibility in the total digestive tract and $N$ retention $(\mathrm{g} /$ day) were greater $(\mathrm{P}<0.05)$ for diets with 16,18 and $20 \%$ CP than for the diets with 12 and 14\% CP. Ruminal ammonia-N concentration increased $(P<0.05)$ with increasing levels of dietary $C P$, however no differences $(P>0.05)$ were observed on $\mathrm{pH}$ and ruminal volatile fatty acids concentration. 


\section{INTRODUÇÃO}

O alto potencial produtivo dos ovinos e o crescente mercado consumidor de carne ovina de qualidade são fatores que, segundo Pires et al. (2000), estimulam a realização de pesquisas com ovinos no Brasil. Souza, citado por Pires et al. (1999), enfatizou que, para que a carne ovina possa disputar maior espaço no mercado de carne brasileiro, o produtor terá que obrigatoriamente investir no sistema criatório, visando a produção de um animal precoce, com adequada quantidade de gordura e grande massa muscular. O cordeiro é a categoria animal que fornece carne de melhor qualidade e apresenta, nesta fase, melhor eficiência de produção devido a sua alta velocidade de crescimento. De acordo com Pires et al. (2000), um método eficiente na produção de carne ovina seria a cria e a terminação de cordeiros em confinamento. Segundo os autores, o ganho de peso do nascimento ao desmame não é sustentado do desmame até ao abate, o que indica a necessidade de alternativas para melhorar o desempenho dos cordeiros nesse período. A combinação de parasitas internos junto com a inabilidade de cordeiros jovens em consumir adequada quantidade de matéria seca, se proveniente de forragem fresca, resultam em ganhos de peso 40 a $60 \%$ inferiores em pastagem em relação a cordeiros mantidos em confinamento (Jordan \& Marten, 1968). Além disso, cordeiros terminados em confinamento apresentam características organolépticas superiores àqueles terminados em pastagem (Touraine, 1984), fato que vem aumentando sua relevância devido ao mercado consumidor tornar-se cada vez mais exigente em relação a aspectos relacionados àqualidade da carne. 
Adicionalmente, no sistema de confinamento, a dieta que apresenta custo mínimo é, na maioria das vezes, a de alta proporção de concentrado (Susin, 2001), cujas vantagens incluem o rápido e mais eficiente crescimento em comparação aos animais criados em forragens que, por sua vez, exigem um período de tempo mais longo para alcançar o peso de abate Notter et al., 1991).

Entre os componentes da dieta de ruminantes, especialmente de ovinos, o nitrogênio expresso como proteína bruta, seja na forma verdadeira ou na forma não protéica, é notadamente um dos ingredientes que recebe especial atenção por de elevado custo. A sua suplementação em níveis adequados é de fundamental relevância para a obtenção de resultados ótimos, principalmente em dietas com altas proporções de concentrado.

Dessa forma, o presente experimento teve como objetivos avaliar a influência de teores crescentes de PB, em dietas com alta proporção de concentrado para cordeiros deslanados, sobre:

- Ganho de peso;

- Consumo de matéria seca;

- Conversão alimentar;

- Digestibilidade dos nutrientes no trato digestivo total,

- Parâmetros ruminais ( $\mathrm{pH}, \mathrm{N}$ amoniacal e AGV),

- Balanço de nitrogênio,

- Concentração de N uréico plasmático. 


\section{REVISÃO DE LITERATURA}

\subsection{Ovinos da raça Santa Inês}

Santa Inês é uma raça ovina deslanada encontrada principalmente na região Nordeste do Brasil. Considera-se que teve sua origem do cruzamento de ovinos da raça Bergamácia de origem italiana com ovinos da raça Crioula e Morada Nova. No contexto da caracterização racial, a Santa Inês é uma raça de porte médio, de acordo com os parâmetros utilizados pelo National Research Council (NRC, 1985a), entretanto, alguns autores consideram-na uma raça de porte grande (Figueiredo et al., 1990; Silva Sobrinho, 1997). As ovelhas adultas pesam entre 60 e $70 \mathrm{~kg}$ e machos adultos entre 80 e $120 \mathrm{~kg}$. Apresenta cabeça de tamanho mediana com perfil semiconvexo e mocha. A coloração da pelagem varia muito entre os animais, podendo ser branca, preta, vermelha ou chitada (Figueiredo et al., 1990; Silva Sobrinho, 1997).

Outra característica relevante da raça, a qual talvez constitua uma das suas principais vantagens sobre as raças lanadas, é o fato de suas matrizes serem poliéstricas anuais. Por ser uma raça de ovino deslanada, formada em região de clima tropical, a estacionalidade reprodutiva é pouco marcante. Dessa forma, a introdução de um reprodutor em lote de fêmeas promoverá em qualquer época do ano a manifestação de estros férteis, permitindo, assim, a formação de lotes homogêneos de acasalamento, parição e desmame ao longo do ano, resultando em constante e homogênea oferta e colocação de carne ovina no mercado consumidor (Traldi, 2001). Além disso, as fêmeas da raça Santa Inês apresentam boa habilidade materna, com produção de leite satisfatória e parição de cordeiros vigorosos (Sousa, 1998). 
As principais características da reprodução dos ovinos Santa Inês têm variado de acordo com as condições de manejo nas quais eles são submetidos. $\mathrm{A}$ idade à puberdade e à primeira parição; fertilidade ao parto, prolificidade e sobrevivência até a desmama relatadas por Sousa (1998) variaram de 196 a 322 dias, 351 a 450 dias, 80 a 95\%, 1,2 a 1,4 e de 75 a 90\%, respectivamente.

Com relação aos aspectos relacionados ao manejo sanitário, os ovinos da raça Santa Inês apresentaram maior resistência a verminose gastrintestinal quando comparados com ovinos lanados (Amarante, 2001) e deslanados (Costa et al., 1986).

Apesar de ser uma raça considerada de dupla aptidão, produtora de pele e carne, Barros et al. (1996) consideram, dentre as raças ovinas predominantes no Nordeste, a raça Santa Inês a que apresenta melhores ganhos de peso em confinamento, podendo chegar a $267 \mathrm{~g} / \mathrm{dia}$. Esses resultados também foram verificados na região Sudeste, em confinamento de cordeiros Santa Inês, por Morais et al. (1999), Mendes et al. (2000) e Susin et al. (2000), os quais obtiveram ganhos de peso de 297, 278 e $268 \mathrm{~g} /$ dia, respectivamente.

De um modo geral, os ovinos da raça Santa Inês têm conquistado espaço em várias regiões do país devido à sua grande capacidade de adaptação e a um potencial aceitável de produção, tendo sua demanda e importância aumentada significativamente nos últimos anos (Sousa \& Morais, 2000).

\subsection{Metabolismo de Nitrogênio em Ovinos}

Devido aos aspectos anatômicos e fisiológicos do aparelho digestivo dos ovinos, os alimentos ingeridos são degradados primeiramente no rúmen, por ação dos microrganismos, antes de sofrerem a digestão enzimática no abomaso e intestino (Teixeira, 1996). Grande parte da proteína verdadeira da dieta é convertida em compostos simples, contendo nitrogênio como amônia, aminoácidos e peptídeos (fontes de nitrogênio para a síntese de proteína 
microbiana). Os microrganismos ruminais, junto com a proteína dietética que escapa da degradação no rúmen, suprem o intestino delgado com proteína para digestão e absorção. Segundo o NRC (1985a), os compostos nitrogenados absorvidos são utilizados, em sua maioria, para crescimento dos tecidos musculares, produção de leite, produção de lã, concepção e outros, tais como hormônios, enzimas, etc.

A otimização na utilização do nitrogênio dietético pelos ruminantes iniciase com a formulação da dieta, especialmente visando sua composição em termos de nitrogênio (PB), energia e outros nutrientes, além do comportamento da dieta no trato digestivo do animal em termos da sua digestibilidade, produção de ácidos graxos voláteis, síntese de proteína microbiana e outros processos metabólicos (Teixeira, 1996).

\subsubsection{Dinâmica do Nitrogênio Ruminal}

O estabelecimento de condições sob as quais a fermentação ruminal será otimizada requer 0 entendimento das exigências de nutrientes para a população microbiana. A digestão de proteína no rúmen resulta na produção de peptídeos. Estes serão mais tarde hidrolisados a aminoácidos, os quais poderão ser deaminados, produzindo amônia. Todas as maiores comunidades microbianas do rúmen (bactérias, protozoários e fungos) podem hidrolisar proteína e usar os produtos finais como fontes de $\mathrm{N}$ para crescimento (Hoover \& Stokes, 1991). Assim, a degradação ruminal de proteína (proteólise) determina a produção de $\mathrm{N}$ amoniacal, aminoácidos, peptídeos e ácidos graxos de cadeia ramificada, os quais influenciam diretamente a taxa de crescimento microbiano no rúmen. A taxa e extensão da proteólise ruminal não somente afeta a síntese de proteína microbiana mas também a quantidade e qualidade da proteína dietética não degradável que alcança o duodeno (Stern et al., 1994). 
Os microrganismos ruminais geralmente contém 20 a 60\% proteína bruta na matéria seca. As fontes de nitrogênio usadas pelos microrganismos para síntese protéica consistem de peptídeos e aminoácidos, resultantes da hidrólise de proteínas, e do nitrogênio não protéico, principalmente amônia (Owens \& Zinn, 1988). O crescimento microbiano pode ser afetado pela disponibilidade dos fatores que compõem as exigências nutricionais dos microrganismos do rúmen, como carboidratos, amônia, peptídeos, aminoácidos, enxofre e ácidos graxos voláteis de cadeia ramificada (Sniffen et al., 1993).

A amônia no rúmen pode ser derivada da degradação da proteína ou do nitrogênio não-protéico da dieta, da hidrólise da uréia reciclada ou da degradação de proteína microbiana e desaparecer do rúmen através do uso pelos microrganismos, absorção pela parede ruminal ou fluxo para o omaso (Owens \& Zinn, 1988). A carência de amônia no rúmen pode limitar o crescimento microbiano, mas, quando a taxa de produção de amônia excede às necessidades microbianas, o excesso é absorvido através do epitélio ruminal, sendo convertido no fígado em uréia. Aproximadamente de 23 a $92 \%$ da uréia plasmática é reciclada pelo trato digestivo, voltando ao rúmen através da saliva ou através da parede ruminal. Hart \& Glimp (1991) observaram valores reduzidos de amônia ruminal (3,55 e 4,03 mg/100 ml), a qual foi consistente com a baixa concentração protéica (11,3 e 10,7\% PB) e alta concentração energética da dieta, a qual teria estimulado a síntese microbiana e utilização dos níveis de amônia disponíveis. Já Hussein et al. (1991), avaliando dietas com fontes protéicas (farelo de soja e farinha de peixe) contendo 15,5\% PB, verificaram que a concentração de amônia ruminal foi menor para a dieta com farinha de peixe $(27 \mathrm{mg} / 100 \mathrm{ml})$ em relação à dieta com farelo de soja (35 $\mathrm{mg} / 100 \mathrm{ml}$ ), o que foi atribuído à menor degradação ruminal da proteína da farinha de peixe.

A concentração de amônia no rúmen não é constante nas 24 horas, apresentando oscilações, com picos obtidos geralmente 1 a 2 horas após a alimentação (Faria \& Huber, 1984; Rihani et al. , 1993). 
Qualquer minimização nas perdas de nitrogênio está relacionada com a maior eficiência do rúmen em utilizar o nitrogênio dietético. Surge, então, o conceito da sincronização do suprimento energético e protéico, uma vez que a síntese de proteína microbiana depende de ATP, o qual é derivado da fermentação de carboidrato (Orskov, 1992). As respostas de animais em crescimento ou lactação aos efeitos combinados da ingestão de proteína e energia indicam uma resposta quadrática do balanço de $\mathrm{N}$ a níveis crescentes do suprimento de proteína quando a energia não é limitada. A uma dada ingestão de energia acima das exigências mínimas, a produção de proteína responde curvilinearmente à ingestão de proteína. A produção através da ingestão de proteína depende do nível de energia suprido, e vice-versa, dentro de uma amplitude normal de consumo (Chowdhury \& Orskov, 1997).

\subsubsection{Produção de Ácidos Graxos Voláteis no Rúmen}

Os maiores substratos para fermentação no rúmen são carboidratos complexos originados de células vegetais, os quais consistem, principalmente, de celulose, hemicelulose, pectinas, amidos, dextranas e carboidratos solúveis. Os principais produtos finais desta fermentação são os ácidos graxos voláteis (principalmente acetato, propionato e butirato) e gases (dióxido de carbono e metano). Em geral, a produção de ácidos graxos voláteis (AGV) representa aproximadamente $75 \%$ da quantidade de energia dos carboidratos e os $25 \%$ remanescentes são usados pelos microrganismos para crescimento ou perdidos como hidrogênio ou metano. Além da fermentação de carboidratos, proteólise é outro processo fermentativo que produz peptídeos e aminoácidos os quais podem ser usados para processos energéticos ou biossintéticos. Aminoácidos podem ser deaminados para formar amônia, dióxido de carbono e ácidos graxos voláteis. Proteólise produz não somente acetato, propionato e butirato mas também ácidos graxos de cadeia ramificada. Estes são principalmente isobutirato, isovalerato e 2-metilbutirato os quais são 
provenientes dos aminoácidos de cadeia ramificada valina, leucina e isoluecina (Bergman, 1990).

Os ácidos graxos voláteis (AGV) constituem a maior fonte de energia para os ruminantes, provendo 50 a $85 \%$ da energia metabolizável pelo animal. Apesar de variações da população microbiana e de diferenças na ingestão, a proporção ruminal de AGV varia muito pouco com razões molares (moles de acetato:propionato:butirato) geralmente sendo próximas a 65:25:10 para dietas com alta proporção de forragem e 50:40:10 para dietas com alta proporção de concentrado, dependendo do $\mathrm{pH}$ (Owens \& Goetsch, 1988).

A concentração total e a respectiva quantidade de cada AGV no rúmen dependem tanto da composição da ração quanto do regime alimentar. Apesar de altamente variável, a quantidade total de AGV geralmente situa-se entre $60 \mathrm{e}$ 150 mM. Em geral, a concentração de acetato predomina sob variadas condições, entretanto, quantidades substanciais de propionato e butirato estão sempre presentes. Valerato e outros geralmente constituem menos que $5 \%$ do total. Dietas ricas em amido, como as dietas com alta proporção de concentrado favorecem a produção de propionato, assim como dietas ricas em forragem favorecem a produção de acetato. $\mathrm{O}$ pH do fluido ruminal geralmente encontrase entre 5,8 e 6,8, mas a taxas de fermentação elevadas pode apresentar valores abaixo de 5,0 (Bergman, 1990). De acordo com Owens \& Goetsch (1988), para dietas com alta proporção de concentrado, espera-se valores de $\mathrm{pH}$ entre 5,5 e 6,5. Os mesmos autores citam que o tempo após a alimentação quando o $\mathrm{pH}$ é o mais baixo geralmente ocorre entre 1 a 4 horas, refletindo o balanço entre as taxas de produção de ácido, de produção de tamponantes da saliva e de presença ou liberação tamponantes ou bases do alimento.

Silva \& Leão (1979) citam que dietas que continham grande quantidade de proteína, ocasionaram um decréscimo na proporção relativa de ácido acético e aumento na proporção de ácido butírico. Os ácidos graxos de cadeia ramificada originam-se dos subprodutos de degradação da proteína. Após a ingestão de uma alimentação rica em proteína pode-se observar uma 
correlação entre a concentração de amônia e a dos ácidos de cadeia ramificada no rúmen.

\subsubsection{Considerações sobre o Metabolismo de N Pós Ruminal}

A avaliação do perfil dos aminoácidos que passam para o intestino depende sobremaneira da composição em aminoácidos da dieta e da proteína microbiana. Além destes, chegam ao intestino amônia e outros compostos nitrogenados não protéicos. Caracteristicamente, o intestino delgado é o principal local de absorção de aminoácidos, podendo também ocorrer a absorção de amônia e outros compostos nitrogenados (Teixeira, 1996). O aumento da ingestão de aminoácidos acima das exigências aumenta a sua oxidação, sugerindo que o excesso de aminoácidos essenciais, devido à alta absorção pelo trato gastrintestinal ou ao relativo excesso em função da escassez de um ou mais aminoácidos (desbalanço), são removidos pela oxidação no fígado (NRC, 1985b).

O nitrogênio transformado em uréia, proveniente da deaminação de aminoácidos ou amônia absorvida do trato gastrintestinal, é excretado pela urina, leite, ou retorna ao trato digestivo. Dessa maneira, a concentração de uréia no sangue é influenciada pela extensão na qual os aminoácidos absorvidos são oxidados e pela absorção de amônia do rúmen, refletindo substancialmente a extensão do balanço de $\mathrm{N}$ da dieta, considerando-se tanto as exigências dos microrganismos ruminais como as do animal hospedeiro (Orskov, 1992). Kennedy \& Milligan (1980) verificaram uma forte correlação positiva entre concentração de uréia plasmática e concentração de amônia ruminal. Em outras palavras, altos níveis de $\mathrm{N}$ urinário indicam altos consumos de nitrogênio inorgânico ou de proteína de rápida digestão ruminal, resultando em produção de amônia acima das necessidades microbianas. A amônia em excesso é absorvida pela corrente sangüínea, convertida em uréia no fígado e excretada na urina (Van Soest, 1994). 
Dessa forma, o nitrogênio total urinário excretado compreende uma fração endógena, relativamente constante por unidade de peso do animal, e uma exógena que varia com a quantidade e qualidade da proteína ingerida. A parte endógena origina-se da degradação e reposição de estruturas protéicas do corpo e de reações irreversíveis de compostos nitrogenados presentes no corpo animal. A fração exógena representa perda do nitrogênio dietético absorvido através do trato digestivo e nitrogênio dos tecidos envolvidos em reações bioquímicas dos processos de síntese e degradação (NRC, 1985b).

As fezes consistem de material tanto de origem dietética como endógena. O mais significativo fator influenciando a quantidade de matéria seca fecal excretada é a quantidade de matéria seca indigestível consumida. Matéria seca fecal contém material da dieta indigestível, parede celular de bactérias ruminais indigestíveis, células microbianas do ceco e resíduo de muitas substâncias endógenas (enzimas, muco, células de descamação). Animais consumindo dietas que são altamente digestíveis (ou seja, alta proporção de concentrado) excretam fezes com muito pouco material de origem endógena (Merchen, 1988), uma vez que o $\mathrm{N}$ fecal metabólico relaciona-se com a condição nutricional do animal, com a qualidade da dieta, com os níveis de consumo e com a fermentação no intestino grosso (Van Soest, 1994).

\subsection{Exigências Nutricionais de Proteína}

Em um trabalho clássico, Andrews \& Orskov (1970) já enfatizavam a discrepância entre as exigências protéicas de cordeiros estimados por experimentos práticos e os estimados pelos métodos fatoriais, principalmente para animais de crescimento acelerado. Em uma coletânea de trabalhos indicada na Tabela 1, verifica-se uma diversidade ainda muito grande dos níveis protéicos das dietas, as quais contém especificamente proporções elevadas (> $65 \%$ ) de concentrado. 
Tabela 1. Níveis protéicos encontrados na literatura

\begin{tabular}{cl}
\hline$\%$ PB (MS da dieta) & \multicolumn{1}{c}{ Fonte } \\
\hline $11-13$ & Hart \& Glimp (1991) \\
15,5 & Hussein et al. (1991) \\
11 & Matras et al. (1991) \\
$10-18$ & Hatfield et al. (1998) \\
$16,5-23,7$ & Manso et al. (1998a) \\
20 & Goetsch (1999) \\
\hline
\end{tabular}

Segundo o NRC (1985a), as exigências foram determinadas por métodos fatoriais utilizando-se da equação: Proteína Bruta exigida em $\mathrm{g} / \mathrm{d}=$ $(\mathrm{PD}+\mathrm{MFP}+\mathrm{EUP}+\mathrm{DL}+\mathrm{la}) / \mathrm{NPV}$, onde $\mathrm{PD}=$ proteína depositada, $\mathrm{MFP}=$ proteína fecal metabólica, EUP= proteína urinária endógena, $\mathrm{DL}=$ perda pela pele e NPV é o valor de proteína líquida. A proteína depositada em ganho foi estimada pela equação : PD em $\mathrm{g} / \mathrm{d}$ = ganho diário $(\mathrm{kg}) \times(268-29,4 \times \mathrm{ECOG})$, onde energia contida de ganho $(E C O G)=N E_{g}(\mathrm{kcal} / \mathrm{d}) /$ ganho $(\mathrm{g} / \mathrm{d})$. Dessa maneira, as exigências para manutenção e ganho de cordeiros são apresentadas nas Tabelas 2 e 3.

Já o Agricultural Research Council (ARC, 1980), utilizando-se dos conceitos de proteína degradável no rúmen (PDR) e proteína não degradável no rúmen (PDNR), sugere as exigências para manutenção e ganho apresentadas na Tabela 4. 
Tabela 2. Exigências Diárias de Proteína Bruta

\begin{tabular}{|c|c|c|c|c|c|}
\hline \multirow{2}{*}{$\begin{array}{c}\text { Peso vivo } \\
(\mathrm{kg})\end{array}$} & \multirow{2}{*}{$\begin{array}{c}\text { ganho de peso } \\
(\mathrm{g} / \mathrm{d})\end{array}$} & \multicolumn{2}{|c|}{ consumo MS/animal } & \multirow{2}{*}{$\begin{array}{l}\text { NDT } \\
(\mathrm{kg})\end{array}$} & \multirow{2}{*}{$\begin{array}{l}\text { PB } \\
\text { (g) }\end{array}$} \\
\hline & & $(\mathrm{kg})$ & $(\% \mathrm{PV})$ & & \\
\hline \multicolumn{6}{|c|}{ cordeiros recém desmamados- moderado potencial de crescimento } \\
\hline 10 & 200 & 0,50 & 5,0 & 0,40 & 127 \\
\hline 20 & 250 & 1,00 & 5,0 & 0,80 & 167 \\
\hline 30 & 300 & 1,30 & 4,3 & 1,00 & 191 \\
\hline 40 & 345 & 1,50 & 3,8 & 1,16 & 202 \\
\hline \multicolumn{6}{|c|}{ cordeiros recém desmamados- elevado potencial de crescimento } \\
\hline 10 & 250 & 0,60 & 6,0 & 0,48 & 157 \\
\hline 20 & 300 & 1,20 & 6,0 & 0,92 & 205 \\
\hline 30 & 325 & 1,40 & 4,7 & 1,10 & 216 \\
\hline 40 & 400 & 1,50 & 3,8 & 1,14 & 234 \\
\hline
\end{tabular}

Fonte: NRC(1985a)

Tabela 3. Porcentagem de PB e relação concentrado:volumoso em dietas para cordeiros recém desmamados com potencial de crescimento moderado e acelerado.

\begin{tabular}{ccccc}
\hline $\begin{array}{c}\text { Peso vivo } \\
(\mathrm{kg})\end{array}$ & $\begin{array}{c}\text { ganho de peso } \\
(\mathrm{g} / \mathrm{d})\end{array}$ & \multicolumn{2}{c}{ Proporções na dieta(\%) } & PB \\
\cline { 3 - 4 } & 250 & Concentrado & Volumoso & $(\%)$ \\
\hline 10 & 300 & 85 & 10 & 26,2 \\
20 & 325 & 85 & 15 & 16,9 \\
30 & 400 & 85 & 15 & 15,1 \\
$40-60$ & & & &
\end{tabular}


Tabela 4. Exigências de proteína (g/dia) para manutenção e crescimento de cordeiros

\begin{tabular}{|c|c|c|c|c|c|c|}
\hline \multirow{2}{*}{$\begin{array}{c}\text { Peso vivo } \\
(\mathrm{kg})\end{array}$} & & \multicolumn{5}{|c|}{ ganho de peso $(\mathrm{g} / \mathrm{d})$} \\
\hline & & 0 & 50 & 100 & 200 & 300 \\
\hline \multirow[t]{3}{*}{20} & $\mathrm{PNDR}^{1}$ & 0 & 5 & 10 & 25 & \\
\hline & $\mathrm{PDR}^{1}$ & 30 & 35 & 45 & 60 & \\
\hline & PB & 30 & 40 & 55 & 85 & \\
\hline \multirow[t]{3}{*}{30} & PNDR $^{1}$ & 0 & 0 & 0 & 10 & 10 \\
\hline & $\mathrm{PDR}^{1}$ & 35 & 45 & 60 & 85 & 115 \\
\hline & PB & 35 & 45 & 60 & 95 & 125 \\
\hline \multirow[t]{3}{*}{40} & PNDR $^{1}$ & 0 & 0 & 0 & 0 & \\
\hline & $\mathrm{PDR}^{1}$ & 50 & 65 & 75 & 105 & 145 \\
\hline & PB & 50 & 65 & 75 & 105 & 145 \\
\hline
\end{tabular}

Observando-se as exigências propostas por ambos os sistemas fatoriais, verifica-se que as exigências de proteína (g/dia) sugeridas pelo ARC (1980) são mais baixas que as exigências sugeridas pelo NRC (1985a), apontando a necessidade de uma maior averiguação das necessidade protéicas de cordeiros em crescimento. Silva (1999), estudando sobre as exigências protéicas para cordeiros deslanados da raça Santa Inês, encontrou valores maiores aos propostos pelo ARC (1980). Da mesma forma, Silva et al. (2001) verificaram que cordeiros Santa Inês foram mais exigentes em proteína líquida para ganho que cordeiros lanados Ideal e lle de France, sendo os valores de exigência protéica cerca de $20 \%$ superiores aos adotados pelo ARC (1980) para cordeiros entre 20 e $30 \mathrm{~kg}$ de peso vivo.

Andrews \& Orskov (1970) testaram dietas contendo cereais variando na concentração de proteína de 10 a 20\% em três níveis de consumo para machos e fêmeas. Os autores verificaram uma resposta quadrática do ganho de peso (g/dia) em função da concentração de proteína bruta na dieta e, a altos níveis 
de ingestão, não houve um aumento de ganho de peso consistente como resultado do aumento da concentração protéica acima de 17,5\% para animais pesando $20 \mathrm{~kg}$.

Hatfield et al. (1998), avaliando dietas contendo farelo de soja com 10 e $18 \%$ de proteína bruta, observaram um maior consumo, maior taxa de passagem, menor $\mathrm{pH}$ ruminal, maior concentração de ácidos graxos voláteis totais e individuais e maiores níveis sangüíneos de nitrogênio uréico para animais recebendo dieta com $18 \%$ PB. Os autores concluíram que dietas com concentrações protéicas de $18 \%$ resultaram num ambiente ruminal mais favorável para os microrganismos e, conseqüentemente, melhor aproveitamento do alimento e aumento no "status" de energia.

Manso et al. (1998a), ao avaliarem três fontes protéicas com teores de 16,5; 22 e 23,7 \% PB na matéria seca da dieta, observaram que as dietas com os teores mais elevados apresentaram maior consumo, maior ganho de peso diário e melhor conversão alimentar. Os autores atribuem o aumento do consumo a uma maior atividade ruminal e taxa de passagem e sugerem que, devido aos melhores resultados de ganho de peso e conversão alimentar para as dietas com 22 e 23,7\% PB, o suprimento protéico da dieta com 16\% PB talvez seja insuficiente para um crescimento adequado de cordeiros.

\subsection{Utilização do Bagaço de Cana-de-Açúcar em Dietas para Ovinos}

O bagaço de cana-de-açúcar, resultante da moagem da cana, é um alimento que tem grande disponibilidade nas usinas e destilarias, principalmente nas regiões produtoras de açúcar. O bagaço é constituído basicamente de parede celular, sendo pobre em conteúdo celular, apresentando baixa digestibilidade e baixos teores de minerais e proteínas, limitando o seu uso in natura. Burgi (1985), avaliando o bagaço in natura (BIN) como alimento volumoso para bovinos, concluiu que a inclusão deste em dietas de bovinos é viável até níveis próximos a $40 \%$ na matéria seca, uma vez que 
níveis superiores a este resultarão em baixo consumo da dieta e baixo desempenho animal. Por outro lado, submetendo-se o bagaço a pressão de vapor, ocorre melhora no valor nutritivo pois a fibra torna-se mais digestível através da redução do tamanho da partícula. Entretanto, esse tratamento aumenta $45 \%$ o preço da tonelada do bagaço tratado sob pressão de vapor (BTPV) em relação ao bagaço in natura (BIN).

Morais et al. (1999), em um estudo sobre o efeito do uso de níveis crescentes de concentrado em dietas com bagaço de cana-de-açúcar hidrolisado sobre o desempenho de cordeiros confinados, observaram maior ganho de peso diário e melhor conversão alimentar para a dieta com $80 \%$ de concentrado comparado com a dieta com $50 \%$ de concentrado. As dietas continham em média $16 \%$ PB na MS.

Com o objetivo de avaliar a substituição do bagaço de cana-de-açúcar tratado com pressão e vapor (BTPV) pelo bagaço in natura (BIN) em dietas com $80 \%$ de concentrado na matéria seca e $16 \%$ PB, Susin et al. (2000) verificaram que o uso de ambos os tipos de bagaço de cana-de-açúcar em dietas com altos níveis de concentrado proporcionaram desempenhos satisfatórios, sendo que o ganho de peso variou de 240 a $270 \mathrm{~g} /$ dia.

\subsection{Utilização de dietas com alta proporção de concentrado para cordeiros confinados}

A atual situação da ovinocultura no Brasil indica um direcionamento para a intensificação da produção, possibilitando maior controle dos fatores que determinam um produto de melhor qualidade, que alcance o peso ideal de abate em um espaço menor de tempo (Garcia et al., 2001).

De acordo com Siqueira (2000), um bom cordeiro em confinamento deve apresentar as seguintes características: boa conversão alimentar, altas taxas de ganho (mínimo de $200 \mathrm{~g} /$ dia) e adequada deposição de gordura. Dessa forma, é fundamental o planejamento correto do sistema de produção, integrando-se 
harmonicamente a genética, a alimentação e o manejo. Para Gastaldi \& Silva Sobrinho (1998), a maximização do uso de concentrados em confinamento permite rações com maior concentração de nutrientes, o que pode ser interessante quando dispõe-se de animais com alto potencial de ganho de peso. Susin (2001) sugere que, em um sistema de confinamento, a dieta de custo mínimo, muitas vezes, é a de alta proporção de concentrado.

Segundo Thériez (1991), dietas altamente energéticas com baixa quantidade de forragem são eficientes em promover altas taxas de crescimento, uma vez que estas dietas induzem a altas concentrações de ácido propiônico no rúmen, o qual é usado eficientemente para crescimento.

McClure et al. (1995), utilizando cordeiros abatidos para uma mesma profundidade de gordura na altura da $12^{\mathrm{a}}$ e $13^{\mathrm{a}}$ costelas, verificaram que aqueles alimentados com dietas contendo $100 \%$ de concentrado tiveram maiores ganhos de peso (351 × $223 \mathrm{~g} / \mathrm{dia})$ num menor período ( $58 \times 77$ dias) do que cordeiros alimentados em pastagem de gramínea. Murphy et al. (1994) também verificaram que o ganho de peso foi maior para cordeiros alimentados com dietas com 100\% de concentrado (316 g/dia) em relação aos mantidos em pastos de alfafa ( $211 \mathrm{~g} / \mathrm{dia})$, que produziram carcaças mais magras.

Morais et al. (1999), utilizando cordeiros Santa Inês, observaram que o ganho de peso diário aumentou 28,62\% (297 x $231 \mathrm{~g} / \mathrm{dia})$ e a conversão alimentar melhorou 17,47\% (4,3 x 5,4 kg/ kg ganho) na dieta com $80 \%$ de concentrado comparado com $50 \%$ de concentrado, não havendo efeito prejudicial para os animais com o nível elevado de concentrado da dieta. Gastaldi \& Silva Sobrinho (1998), utilizando cordeiros Ideal x Ile de France, observaram que os animais que receberam uma dieta com $70 \%$ de concentrado apresentaram melhor desempenho (171,4 g/dia) em relação aos que receberam a dieta com $50 \%$ (143,7 g/dia). 


\section{MATERIAL E MÉTODOS}

\subsection{Experimento I: Desempenho dos Animais}

\subsubsection{Animais e Instalações Experimentais}

Foram utilizados quarenta e oito cordeiros mestiços da raça Santa Inês com peso médio inicial de $18,4 \pm 0,4 \mathrm{~kg}$ e idade média inicial de $86 \pm 2$ dias. Os animais foram vacinados contra clostridioses (vacina Sintoxan - Lab. Rhodia Mérieux) e everminados antes de iniciar o período experimental. A incidência de verminoses foi controlada através de exames de fezes (OPG).

O experimento foi conduzido na instalação experimental de ovinocultura do Departamento de Produção Animal da ESALQ-USP, Piracicaba, onde os animais foram alojados em baias com piso de concreto com dimensões 4,00 $\mathrm{x}$ $1,35 \mathrm{~m}$, cocho coberto e bebedouros automáticos, sendo distribuídos 2 animais por baia e 6 baias por tratamento.

O município de Piracicaba situa-se no Estado de São Paulo, a $22^{\circ} 42^{\prime} 30^{\prime}$ 'S de latitude e $47^{\circ} 38^{\prime} 01^{\prime \prime} \mathrm{W}$ de longitude, com altitude média de $546 \mathrm{~m}$. A precipitação média anual é de $1.585,4 \mathrm{~mm}$ e as temperaturas médias de máximas e mínimas são 32 e $10^{\circ} \mathrm{C}$, respectivamente (Base de Dados do Posto Agrometeorológico - DCE-ESALQ/USP). 


\subsubsection{Período Experimental e Pesagem dos Animais}

O período experimental teve a duração de 8 semanas e foi constituído por dois sub-períodos de 28 dias de duração. Um período pré-experimental (10 dias) foi utilizado para adaptação à dieta e às instalações experimentais. No início do experimento, os animais foram pesados em jejum para definição dos blocos. As pesagens dos animais foram feitas a cada 28 dias com jejum de 20 horas de alimento.

\subsubsection{Tratamentos e Fornecimento das Dietas}

As dietas foram formuladas para serem isoenergéticas contendo bagaço de cana-de-açúcar in natura e hidrolisado (50:50), milho moído, farelo de soja, uréia, cloreto de amônio, suplemento mineral e calcário calcítico. Todas as dietas tiveram a mesma proporção de $20 \%$ de volumoso (10\% bagaço-de-cana hidrolisado e $10 \%$ bagaço-de-cana in natura) e $80 \%$ de concentrado na matéria seca (MS). Os teores de proteína bruta das dietas foram determinantes dos tratamentos, os quais foram 14, 16, 18 e $20 \%$ de proteína bruta (PB) na MS. A composição das dietas está indicada no Tabela 5.

O alimento volumoso foi misturado previamente numa proporção 50:50 na MS de bagaço de cana-de-açúcar in natura e bagaço de cana-de-açúcar hidrolisado, compactado e armazenado. Da mesma forma, o alimento concentrado foi misturado previamente em um misturador vertical (marca Lucato, capacidade $500 \mathrm{~kg}$ ) e armazenado em tambores de plástico com capacidade para 200 litros. No momento do fornecimento do alimento para os animais pesava-se 0 bagaço de cana-de-açúcar e o concentrado separadamente, os quais eram posteriormente misturados no cocho, objetivando a obtenção de uma ração totalmente homogeneizada. 
Tabela 5. Composição das dietas (\% da MS)

\begin{tabular}{|c|c|c|c|c|}
\hline \multirow[b]{2}{*}{ Ingredientes } & \multicolumn{4}{|c|}{ Tratamentos $^{1}$} \\
\hline & T14 & T16 & T18 & T20 \\
\hline$\overline{\text { BTPV }^{2}}$ & 10 & 10 & 10 & 10 \\
\hline $\mathrm{BIN}^{3}$ & 10 & 10 & 10 & 10 \\
\hline milho moído & 63,7 & 58,7 & 53,4 & 48,3 \\
\hline farelo de soja- $48 \%$ & 11,8 & 16,8 & 22,1 & 27,2 \\
\hline sal mineral ${ }^{4}$ & 2,0 & 2,0 & 2,0 & 2,0 \\
\hline cloreto de amônio & 0,5 & 0,5 & 0,5 & 0,5 \\
\hline uréia & 0,5 & 0,5 & 0,5 & 0,5 \\
\hline calcário & 1,5 & 1,5 & 1,5 & 1,5 \\
\hline
\end{tabular}

Composição bromatológica

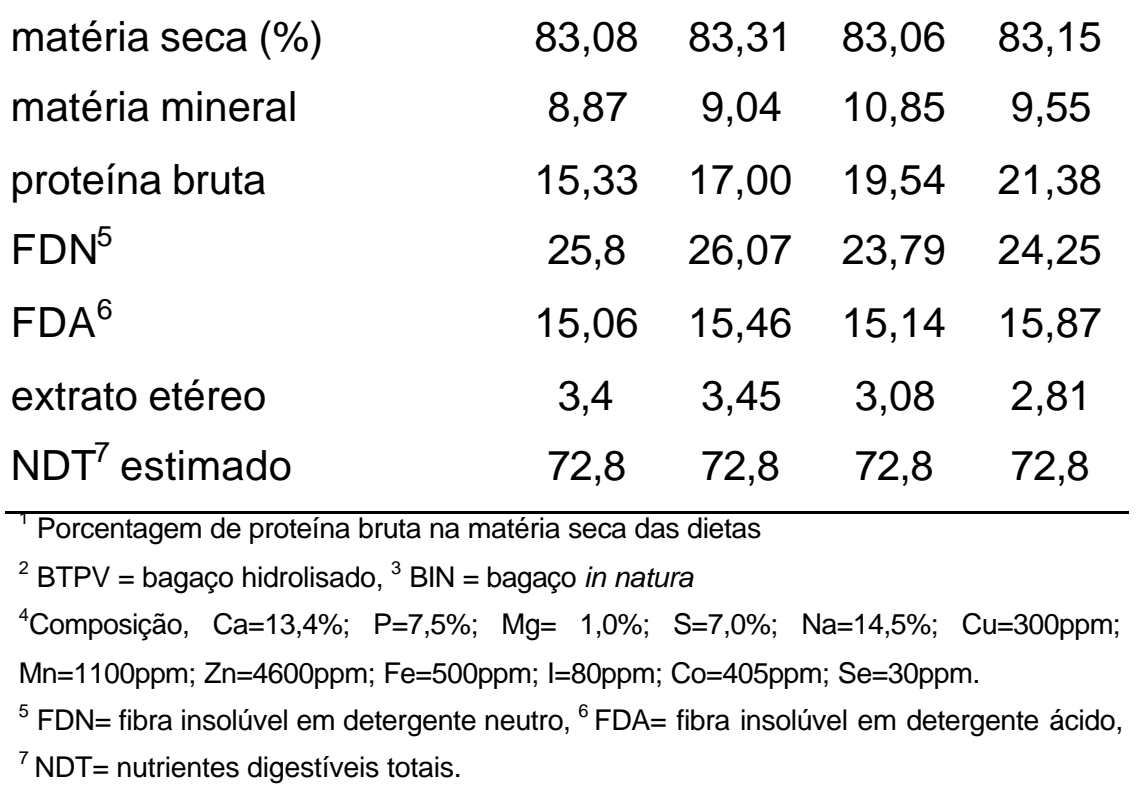

O alimento era fornecido diariamente æ̀̀ 12 horas e as sobras registradas diariamente para determinação do consumo de matéria seca por animal/dia. $O$ alimento oferecido era amostrado semanalmente. As sobras também eram amostradas semanalmente, por baia experimental, numa alíquota de $10 \%$. As amostras foram conservadas, congeladas a $-20^{\circ} \mathrm{C}$ e posteriormente 
descongeladas e secas em estufas de ventilação forçada $\left(55-60^{\circ} \mathrm{C}\right)$ por 72 horas para determinação da matéria seca (MS) de acordo com A.O.A.C. (1990).

As amostras de alimento oferecido e recusado depois de secas foram moídas em um moinho tipo Wiley providos de peneiras de $1 \mathrm{~mm}$ e analisadas para matéria orgânica $(\mathrm{MO})$, extrato etéreo (EE) e proteína bruta $(\mathrm{PB})$ de acordo com A.O.A.C. (1990) e fibra em detergente neutro (FDN) de acordo com Van Soest et al. (1991), fibra em detergente ácido (FDA) de acordo com Goering \& Van Soest (1970) e matéria seca de acordo com o protocolo do Laboratório de Bromatologia do Departamento de Produção Animal da ESALQ.

\subsubsection{Coleta de Sangue}

No início e no $26^{\circ}$ dia de cada sub-período foi colhido sangue de um animal por baia. As amostras de sangue foram colhidas da veia jugular, em tubos de vidro com vácuo contendo oxalato de potássio como anticoagulante e fluoreto de sódio como antiglicolítico, æ̀ 0 e 3 horas após o fornecimento das dietas experimentais. As amostras foram centrifugadas por 20 minutos a $3000 \mathrm{x}$ $g$ e o plasma foi congelado em duplicata para posterior análise. As determinações de nitrogênio uréico plasmático (NUP) foram realizadas de acordo com o método colorimétrico descrito por Chaney \& Marbach (1962) e adaptado para ser usado em placas de microtítulo e lido em aparelho do tipo Elisa Reader BIO RAD (absorbância de 550 nanômetros).

\subsubsection{Abate dos Animais}

Ao final do período experimental foi sorteado um animal por baia para abate e determinação do rendimento de carcaça. Os cordeiros foram pesados com jejum de sólidos de 20 horas, obtendo-se o peso ao abate (PA), e imediatamente sacrificados. Foi obtido o peso da carcaça quente (PCQ) e após seu resfriamento em câmara frigorífica $\left(2^{\circ} \mathrm{C}\right)$ por 24 horas, o peso da carcaça 
fria $(P C F)$. Foram determinados o rendimento da carcaça quente $(R C Q)=$ $(\mathrm{PCQ} / \mathrm{PA}) \times 100$, o rendimento da carcaça fria $(\mathrm{RCF})=(\mathrm{PCF} / \mathrm{PA}) \times 100$ e a quebra por resfriamento $(\mathrm{QR})=\{(\mathrm{PCQ}-\mathrm{PCF}) / \mathrm{PCQ}\} \times 100$.

\subsubsection{Análise Estatística}

O delineamento experimental foi o de blocos ao acaso com quatro tratamentos e seis repetições, sendo os blocos definidos pelo peso inicial.

As variáveis determinadas foram: ganho de peso, consumo de alimento, conversão alimentar, peso da carcaça quente, peso da carcaça fria, rendimento de carcaça quente, rendimento de carcaça fria e quebra por resfriamento. Os dados foram avaliados pelo procedimento GLM (General Linear Models) do pacote estatístico SAS (1991). O quadro de análise da variância está apresentado na Tabela 6.

Tabela 6. Análise da variância para o experimento de desempenho.

\begin{tabular}{lc}
\hline Causas de Variação & Graus liberdade \\
\hline Blocos & 5 \\
Tratamentos & 3 \\
Resíduo & 15 \\
Total & 23 \\
\hline
\end{tabular}

A concentração de $\mathrm{N}$ uréico plasmático foi analisada estatisticamente como parcelas subdivididas no tempo, utilizando-se o PROC MIXED do pacote estatístico SAS (1991). O resumo do quadro de análise da variância está apresentado na Tabela 7. 
Tabela 7. Análise da variância para concentração de uréia plasmática.

\begin{tabular}{lc}
\hline Causas de Variação & Graus liberdade \\
\hline Blocos & 5 \\
Tratamentos & 3 \\
Resíduo A & 15 \\
Sub Total & 23 \\
Tempo & 1 \\
Tempo x tratamento & 7 \\
Resíduo B & 16 \\
Total & 47 \\
\hline
\end{tabular}

Considerou-se o nível de 5\% como significativo para a probabilidade do teste $\mathrm{F}$ na análise de variância. Após detectadas respostas significativas foi realizado o teste de Tukey para se verificar as diferenças entre os tratamentos para as diversas variáveis.

\subsection{Experimento II: Digestibilidade dos nutrientes}

\subsubsection{Animais e Instalações Experimentais}

Foram utilizados cinco ovinos da raça Santa Inês providos de cânulas ruminais, com peso médio inicial de $43 \mathrm{~kg}$ e idade média inicial de 6 meses. Os ovinos foram submetidos àcirurgia para colocação de cânulas no Departamento de Produção Animal da ESALQ-USP.

O experimento foi conduzido na instalação experimental de ovinocultura do Departamento de Produção Animal da Escola Superior de Agricultura Luiz de Queiroz, ESALQ-USP. Os animais foram alojados em gaiolas metabólicas 
individuais com cochos e bebedouros. As gaiolas metabólicas eram metálicas e com dimensões de $1,3 \times 0,55 \mathrm{~m}$.

\subsubsection{Tratamentos}

As dietas foram formuladas para serem isoenergéticas contendo bagaço de cana-de-açúcar in natura, bagaço de cana-de-açúcar hidrolisado, milho moído, farelo de soja, uréia, cloreto de amônio, suplemento mineral e calcário calcítico. Todas as dietas tiveram a mesma proporção de $20 \%$ de volumoso (10\% bagaço-de-cana hidrolisado e $10 \%$ bagaço-de-cana in natura) e $80 \%$ de concentrado na matéria seca (MS). Os teores de proteína bruta das dietas foram determinantes dos tratamentos, os quais foram 12, 14, 16, 18 e $20 \%$ de proteína bruta (PB) na MS. A composição das dietas está indicada no Tabela 8.

O alimento volumoso foi misturado previamente numa proporção 50:50 na MS de bagaço de cana-de-açúcar in natura e bagaço de cana-de-açúcar hidrolisado, compactado e armazenado. Da mesma forma, o alimento concentrado foi misturado previamente em um misturador vertical (marca Lucato, capacidade $500 \mathrm{~kg}$ ) e armazenado em tambores de plástico de 200 litros. No momento do fornecimento do alimento para os animais pesava-se o bagaço de cana-de-açúcar e o concentrado separadamente, os quais eram posteriormente misturados no cocho, objetivando a obtenção de uma ração completa. 
Tabela 8. Composição das dietas (\% da MS)

\begin{tabular}{|c|c|c|c|c|c|}
\hline \multirow[b]{2}{*}{ Ingredientes } & \multicolumn{5}{|c|}{ Tratamentos $^{1}$} \\
\hline & T12 & T14 & $\mathrm{T} 16$ & T18 & T20 \\
\hline BTPV $^{2}$ & 10 & 10 & 10 & 10 & 10 \\
\hline $\mathrm{BIN}^{3}$ & 10 & 10 & 10 & 10 & 10 \\
\hline milho moído & 68,8 & 63,7 & 58,7 & 53,4 & 48,3 \\
\hline farelo de soja-48\% & 6,7 & 11,8 & 16,8 & 22,1 & 27,2 \\
\hline sal mineral ${ }^{4}$ & 2,0 & 2,0 & 2,0 & 2,0 & 2,0 \\
\hline cloreto de amônio & 0,5 & 0,5 & 0,5 & 0,5 & 0,5 \\
\hline uréia & 0,5 & 0,5 & 0,5 & 0,5 & 0,5 \\
\hline calcário & 1,5 & 1,5 & 1,5 & 1,5 & 1,5 \\
\hline
\end{tabular}

Composição bromatológica (\% na MS)

\begin{tabular}{lccccc} 
matéria seca & 82,6 & 82,6 & 82,2 & 82,8 & 81,8 \\
matéria mineral & 6,1 & 6,6 & 6,0 & 7,2 & 6,8 \\
matéria orgânica & 93,9 & 93,4 & 94,0 & 92,8 & 93,2 \\
proteína bruta & 12,6 & 14,3 & 16,0 & 18,2 & 20,2 \\
FDN $^{5}$ & 32,4 & 33,9 & 33,9 & 33,4 & 33,1 \\
$\mathrm{FDA}^{6}$ & 20,8 & 23,9 & 23,1 & 23,2 & 22,8 \\
extrato etéreo $_{\mathrm{NDT}^{7} \text { estimado }}^{3,9}$ & 3,8 & 4,1 & 3,8 & 3,3 \\
\hline
\end{tabular}

Porcentagem de proteína bruta na matéria seca das dietas

${ }^{2} \mathrm{BTPV}=$ bagaço hidrolisado, ${ }^{3} \mathrm{BIN}=$ bagaço in natura

4 Composição, $\mathrm{Ca}=13,4 \% ; \mathrm{P}=7,5 \% ; \mathrm{Mg}=1,0 \% ; \mathrm{S}=7,0 \% ; \mathrm{Na}=14,5 \% ; \mathrm{Cu}=300 \mathrm{ppm} ; \mathrm{Mn}=1100 \mathrm{ppm} ; \mathrm{Zn}=4600 \mathrm{ppm}$; $\mathrm{Fe}=500 \mathrm{ppm} ; \mathrm{I}=80 \mathrm{ppm} ; \mathrm{Co}=405 \mathrm{ppm} ; \mathrm{Se}=30 \mathrm{ppm}$.

${ }^{5}$ FDN= fibra insolúvel em detergente neutro, ${ }^{6}$ FDA = fibra insolúvel em detergente ácido, ${ }^{7}$ NDT= nutrientes digestíveis totais. 


\subsubsection{Período Experimental}

O período experimental teve a duração de 10 semanas. Utilizou-se 5 períodos de 14 dias cada, sendo 9 dias de adaptação e 5 dias de coleta. Os animais foram pesados por três dias consecutivos sem jejum durante o início de cada período e no final do experimento.

\subsubsection{Coleta das amostras do alimento oferecido e recusado, fezes e urina.}

O alimento era fornecido diariamente æ̇̀ 07 horas e as sobras registradas diariamente, sendo que do décimo ao décimo terceiro dia de cada período os dados foram utilizados para determinação do consumo de matéria seca por animal/dia. Os alimentos oferecidos e recusados foram amostrados diariamente do décimo ao décimo terceiro dia de cada período e congelados a $-20^{\circ} \mathrm{C}$. As amostras de fezes foram coletadas do décimo ao décimo terceiro dia de cada período em quantidade total e congeladas a $-20^{\circ} \mathrm{C}$. Posteriormente, as amostras foram descongeladas, compostas por animal e período e secas em estufas de ventilação forçada $\left(55-60^{\circ} \mathrm{C}\right)$ por 72 horas para determinação da matéria seca (MS) de acordo com A.O.A.C. (1990).

As amostras de oferecido, recusado e fezes, depois de secas, foram moídas em um moinho tipo Wiley providos de peneiras de $1 \mathrm{~mm}$ e analisadas para matéria orgânica $(\mathrm{MO})$, extrato etéreo (EE) e proteína bruta $(\mathrm{PB})$ de acordo com A.O.A.C. (1990), fibra em detergente neutro (FDN) de acordo com Van Soest et al. (1991), fibra em detergente ácido (FDA) de acordo com Goering \& Van Soest (1970) e matéria seca de acordo com o protocolo do Laboratório de Bromatologia do Departamento de Produção Animal da ESALQ.

As amostras de urina foram coletadas do décimo ao décimo terceiro dia de cada período em vasilhame apropriado com $30 \mathrm{ml}$ de $\mathrm{HCl} 6 \mathrm{~N}$, adicionado para manter o pH abaixo de 3,0. Uma alíquota de $10 \%$ de urina foi amostrada 
diariamente e congelada a $-20^{\circ} \mathrm{C}$. Posteriormente, as amostras foram descongeladas, compostas por animal e período e analisadas para Nitrogênio de acordo com A.O.A.C. (1990).

Utilizaram-se as seguintes equações para os cálculos de digestibilidade e balanço de N:

1- Digestibilidade aparente do Nutriente (\%)

$=[(\mathrm{MS}$ consumida $\mathrm{x} \%$ do nutriente na MS $)-(\mathrm{MS}$ fecal $\mathrm{x} \%$ do nutriente na MS fecal) / (MS consumida $\times \%$ do nutriente na MS)] x 100

2- Balanço de $\mathrm{N}$ ( $\mathrm{g} / \mathrm{dia})$

$=\mathrm{N}_{\text {consumido }}-\mathrm{N}_{\text {fezes }}-\mathrm{N}_{\text {urina }}$

3- Balanço de $\mathrm{N}$ (\% $\mathrm{N}$ consumido)

$=\left[\left(\mathrm{N}_{\text {consumido }}-\mathrm{N}_{\text {fezes }}-\mathrm{N}_{\text {urina }}\right) / \mathrm{N}_{\text {consumido }}\right] \times 100$

4- Balanço de $\mathrm{N}$ (\% $\mathrm{N}$ digerido)

$=\left[\left(\mathrm{N}_{\text {consumido }}-\mathrm{N}_{\text {fezes }}-\mathrm{N}_{\text {urina }}\right) /\left(\mathrm{N}_{\text {consumido }} \times\right.\right.$ Digestibilidade aparente $\left.\left.\mathrm{N}\right)\right] \mathrm{x}$ 100

\subsubsection{Coleta de Fluido Ruminal}

As amostras de fluido ruminal foram coletadas no último dia de cada período, com intervalos de 2 horas. Os tempos de coleta foram determinados obedecendo aos horários da alimentação, sendo o tempo 0 antes do fornecimento da dieta. Depois de coletadas, as amostras do conteúdo ruminal foram filtradas em duas camadas de tecido de algodão (fraldas) obtendo-se dessa forma aproximadamente $200 \mathrm{ml}$ de filtrado. Depois da filtragem, o conteúdo foi dividido em duas porções. A primeira foi utilizada para aferir o $\mathrm{pH}$ ruminal através da leitura direta em um potenciômetro digital da Digimed, modelo TE-902. Da segunda porção, foi coletada uma quantia de $25 \mathrm{ml}$ a qual sofreu um acréscimo de $1,25 \mathrm{ml}$ de ácido clorídrico $6 \mathrm{~N}$ e foi congelada a $-10^{\circ} \mathrm{C}$ para posterior análise. 
As amostras de fluido ruminal foram descongeladas, centrifugadas a $11.000 \times \mathrm{g}$ a $4^{\circ} \mathrm{C}$, durante 40 minutos e uma porção de $800 \mu \mathrm{L}$ do sobrenadante foi utilizado para análise de AGV de acordo com Palmquist \& Conrad (1971), utilizando um cromatógrafo líquido gasoso (CLG) Hewlett Packard 5890, series II (Hewlett - Packard Company, Avondale, PA) e equipado com Integrador HP (Hewlett - Packard Company, Avondale, PA). Foi utilizado nitrogênio como gás de arraste e as temperaturas do injetor, detector e coluna foram 150, 190 e $115^{\circ} \mathrm{C}$, respectivamente.

As amostras de fluido ruminal para determinação de nitrogênio na forma

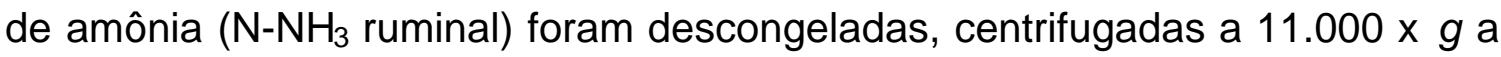
$4^{\circ} \mathrm{C}$, durante 20 minutos e uma porção de $30 \mu \mathrm{L}$ do sobrenadante foi utilizada para análise da concentração de $\mathrm{N}^{-\mathrm{NH}_{3}}$ ruminal de acordo com o método colorimétrico descrito por Chaney \& Marbach (1962) e adaptado para ser usado em placas de microtítulo e lido em aparelho do tipo Elisa Reader BIO RAD (absorbância 550 nanômetros).

\subsubsection{Análise Estatística}

O delineamento experimental utilizado foi um quadrado latino $5 \times 5$, sendo cinco animais e cinco períodos.

Os dados relativos ao ensaio de digestibilidade foram avaliados pelo procedimento GLM (General Linear Models) do pacote estatístico SAS (1991),

O quadro de análise da variância está apresentado na Tabela 9.

Os parâmetros ruminais ( $\mathrm{pH}, \mathrm{AGVs}$ e $\mathrm{N}-\mathrm{NH}_{3}$ ruminal) foram analisados estatisticamente como parcelas subdivididas no tempo pelo procedimento MIXED do pacote estatístico SAS (1991). Os efeitos de tratamento, animal e período foram testados com relação æ̀ parcelas. O horário de coleta (tempo) e a interação tempo (horário de coleta) x tratamento foi testada com relação às subparcelas. O quadro de análise da variância está apresentado na Tabela 10. 
Tabela 9. Análise da variância para o experimento de digestibilidade.

\begin{tabular}{lc}
\hline Causa de Variação & Graus liberdade \\
\hline Animal & 4 \\
Período & 4 \\
Tratamentos & 4 \\
Resíduo & 12 \\
Total & 24 \\
\hline
\end{tabular}

Considerou-se o nível de 5\% como significativo para a probabilidade do teste $\mathrm{F}$ na análise de variância. Após detectadas respostas significativas foi realizado o teste de Tukey para se verificar as diferenças entre os tratamentos para as diversas variáveis.

Tabela 10. Análise da variância para o experimento de digestibilidade.

\begin{tabular}{lc}
\hline Causa de Variação & Graus liberdade \\
\hline Animal & 4 \\
Período & 4 \\
Tratamentos & 4 \\
Resíduo A & 12 \\
Sub Total & 24 \\
Tempo & 6 \\
Tempo x Tratamento & 24 \\
Resíduo B & 120 \\
Total & 174 \\
\hline
\end{tabular}




\section{RESULTADOS E DISCUSSÃO}

\subsection{Experimento I: Desempenho dos Animais}

\subsubsection{Ganho de Peso Vivo}

Os dados observados relativos ao ganho de peso vivo (GPV) estão apresentados na Tabela 11, onde verifica-se que não houve diferença $(P>$ $0,05)$ entre os tratamentos.

Em geral, o ganho de peso vivo obtido neste experimento foi satisfatório. Outros estudos verificaram, em comparação com outras raças, ganho de peso médio de $160 \mathrm{~g} / \mathrm{animal} / \mathrm{dia}$ para borregos mestiços Santa Inês confinados (Vasconcelos et al., 2000) e ganho de peso de $216 \mathrm{~g} / \mathrm{dia}$ para cordeiros Santa Inês alimentados com dietas com $83 \%$ de concentrado e $18 \%$ de PB (Pérez et al., 1998). Entretanto, desempenhos melhores têm sido relatados para cordeiros Santa Inês, onde se observaram ganhos de peso de $297 \mathrm{~g} / \mathrm{dia}$ (Morais et al., 1999) e $240 \mathrm{~g} / \mathrm{dia}$ (Susin et al., 2000) para cordeiros alimentados com dietas de bagaço de cana-de-açúcar e $80 \%$ de concentrado composto de milho, farelo de soja e minerais. Monteiro et al. (1998) encontraram ganho de peso de $281 \mathrm{~g} /$ dia para cordeiros Santa Inês alimentados com dietas com 80\% de concentrado e $17 \%$ PB. 
Tabela 11. Peso vivo e Ganho de peso (GPV) dos cordeiros no período experimental.

\begin{tabular}{|c|c|c|c|c|c|c|}
\hline & \multicolumn{4}{|c|}{ Tratamentos $^{1}$} & \multirow[b]{2}{*}{$\mathrm{EPM}^{2}$} & \multirow[b]{2}{*}{--P-- } \\
\hline & T14 & T16 & T18 & T20 & & \\
\hline Peso Inicial, kg & 18,0 & 18,4 & 18,5 & 18,6 & 0,40 & 0,674 \\
\hline Peso Final, kg & 30,8 & 30,7 & 31,4 & 31,5 & 0,69 & 0,768 \\
\hline \multicolumn{7}{|l|}{ GPV, g/dia } \\
\hline Período 1 & 210 & 211 & 230 & 231 & 13,86 & 0,567 \\
\hline Período 2 & 246 & 228 & 229 & 230 & 8,17 & 0,388 \\
\hline Média & 228 & 220 & 230 & 231 & 8,20 & 0,788 \\
\hline
\end{tabular}

Alguns trabalhos verificaram uma melhora no ganho de peso de cordeiros alimentados com teores crescentes de proteína bruta na dieta. Muwala et al. (1998) observaram ganhos de peso de 185 e $228 \mathrm{~g} / \mathrm{animal} / \mathrm{dia}$ para dietas com 12,8 e 15,4\% PB na matéria seca, respectivamente. Em outro estudo, avaliando rações contendo 12, 14, 16 e 18\% PB, Titi et al. (2000) verificaram melhores ganhos de peso para as dietas com 16 e $18 \% \mathrm{~PB}$, cujos valores foram 99, 171, 208 e $189 \mathrm{~g} / \mathrm{animal} / \mathrm{dia}$, respectivamente. Zundt et al. (2001a) indicaram efeito linear dos teores protéicos (12, 16, 20 e 24\%) para ganho de peso, mostrando um aumento de $1,5 \mathrm{~g} /$ dia para $1 \%$ de aumento no teor de proteína dietética, porém os ganhos de peso observados (média geral de $162 \mathrm{~g} / \mathrm{dia}$ ) foram inferiores aos relatados neste trabalho.

Por outro lado, Haddad et al. (2001) sugeriram um teor ótimo de $16 \%$ de proteína bruta (PB) na dieta para cordeiros da raça Awassi, acima do qual não se teriam resultados no aumento de produção. Outros autores, ao estudarem dietas com 15 e 18\% de PB, não verificaram resposta entre os tratamentos, sugerindo que os efeitos da dieta no desempenho foram mais agregados á concentração energética do que ao nível ou fonte de proteína da dieta (Beauchemin et al., 1995). 


\subsubsection{Consumo de matéria seca e conversão alimentar}

Conforme verifica-se na Tabela 12, no período 1 o consumo de matéria seca foi maior $(P<0,05)$ para as dietas com 18 e $20 \%$ PB em relação à com 14 e $16 \%$ PB. No entanto, esse aumento não foi verificado no período 2 . A média dos períodos reflete o comportamento obtido durante o ensaio, onde se verifica que não houve efeito $(P>0,05)$ de tratamento sobre o consumo de matéria seca (Tabela 12).

O consumo diário de ração dos cordeiros observado na Tabela 12 encontra-se próximo da média recomendada pelo NRC (1985a) para ovinos desta categoria que é entre 1,0 a 1,3 kg MS/ animal/dia e está de acordo com o consumo encontrado por Morais et al. (1999) e Susin et al. (2000) para cordeiros Santa Inês alimentados com dietas com $20 \%$ bagaço de cana-deaçúcar e $80 \%$ de concentrado (1,24 e 1,0 kg MS/animal/dia, respectivamente).

Alguns trabalhos não observaram efeito da concentração de PB da dieta na ingestão de matéria seca Beauchemin et al., 1995; Zundt et al.,2001a). Manso et al. (1998b) verificaram um consumo médio de matéria seca de 77,5 g/ $\mathrm{kg} \mathrm{PV}^{0,75}$ para cordeiros alimentados com dietas com alta proporção de concentrado contendo 14 e 26\% PB. Em contraste, Manso et al. (1998a) observaram um aumento de $9 \%$ no CMS para cordeiros alimentados com 21,3 e $23,7 \%$ PB em comparação aos alimentados com 16,5\%. A menor ingestão associada com a menor concentração protéica da dieta está em acordo com os resultados reportados por Fluharty \& Mcclure (1997), Muwalla et al. (1998), Haddad et al. (2001) e Arsenos \& Kyriazakis (2001) para cordeiros em crescimento alimentados com diferentes suplementos protéicos. 
Tabela 12. Consumo de matéria seca (CMS) e conversão alimentar (CA) dos cordeiros no período experimental.

\begin{tabular}{|c|c|c|c|c|c|c|}
\hline & \multicolumn{4}{|c|}{ Tratamentos $^{1}$} & \multirow[b]{2}{*}{$\mathrm{EPM}^{2}$} & \multirow[b]{2}{*}{$-P_{-}$} \\
\hline & T14 & T16 & T18 & T20 & & \\
\hline \multicolumn{7}{|l|}{ CMS, kg/dia } \\
\hline Período 1 & $0,895^{b}$ & $0,913^{b}$ & $0,992^{\mathrm{a}}$ & $0,998^{a}$ & 0,02 & 0,014 \\
\hline Período 2 & 1,177 & 1,127 & 1,177 & 1,211 & 0,04 & 0,552 \\
\hline Média & 1,035 & 1,022 & 1,083 & 1,103 & 0,03 & 0,224 \\
\hline \multicolumn{7}{|c|}{ CMS, g/ kg PV 0,75} \\
\hline Período 1 & $83,0^{b}$ & $82,9^{b}$ & $88,6^{a}$ & $88,9^{a}$ & 2,18 & 0,002 \\
\hline Período 2 & 90,5 & 86,1 & 88,3 & 90,9 & 2,18 & 0,637 \\
\hline Média & 86,8 & 84,2 & 88,4 & 89,9 & 1,54 & 0,250 \\
\hline \multicolumn{7}{|c|}{ CA, kg MS/ kg ganho } \\
\hline Período 1 & 3,94 & 4,12 & 3,97 & 4,01 & 0,15 & 0,876 \\
\hline Período 2 & 4,47 & 4,55 & 4,72 & 4,89 & 0,23 & 0,588 \\
\hline Média & 4,19 & 4,28 & 4,35 & 4,44 & 0,11 & 0,504 \\
\hline
\end{tabular}

Não houve diferença $(P>0,05)$ nos resultados obtidos para a conversão alimentar, sendo esses próximos aos obtidos por Morais et al. (1999) e Susin et al. (2000), cujos valores foram 4,3 e 3,89 kg MS/ kg ganho, respectivamente. Entretanto, os valores obtidos neste experimento revelaram uma melhor conversão em comparação aos resultados citados por Perez et al. (1998) que encontraram valores de CA de 6,26 para cordeiros Santa Inês e 6,05 para Bergamácia, alimentados com dieta contendo $83 \%$ de concentrado e teores crescentes de dejetos de suíno. Muwalla et al. (1998), Beauchemin et al. (1995) e Haddad et al. (2001) também não verificaram efeito na conversão alimentar de cordeiros alimentados com dietas com teores crescentes de proteína, cujos valores médios foram 5,8; 3,7 e 4,5 kg MS/ kg ganho; respectivamente. 


\subsubsection{Consumo de proteína bruta}

O consumo de proteína bruta dos cordeiros, em g/dia e g/kg peso metabólico $\left(\mathrm{PV}^{0,75}\right)$, está apresentado na Tabela 13. Como era esperado, o consumo de proteína bruta aumentou com a elevação do teor protéico da dieta, entretanto, esse maior consumo não refletiu em maiores ganhos de peso (Tabela 11).

Pérez et al. (1998) encontraram consumo médio de proteína bruta de $230,7 \mathrm{~g} / \mathrm{dia}$ ou $11,7 \mathrm{~g} / \mathrm{kg} \mathrm{PV} \mathrm{PV}^{0,75}$ para cordeiros Santa Inês alimentados com dietas com $83 \%$ de concentrado e $18 \%$ de PB.

Segundo o NRC (1985a), para animais com genótipo de tamanho médio, a exigência protéica para um cordeiro com $25 \mathrm{~kg}$ e ganho diário de $250 \mathrm{~g} / \mathrm{dia}$ é de $174 \mathrm{~g} / \mathrm{dia}$. Entretanto, consumos acima de $220 \mathrm{~g} / \mathrm{dia}$ de proteína bruta permitiriam ganhos superiores a $300 \mathrm{~g} / \mathrm{dia}$ para animais com o genótipo citado acima. Dessa forma, apesar dos animais nas dietas com 18 e $20 \%$ PB terem consumido quantidades elevadas de proteína bruta (218,5 e 242,9, respectivamente), estes não conseguiram expressar seu potencial de ganho. Isso pode ter sido conseqüência de uma infestação de Eimeria que ocorreu durante a terceira semana do período experimental e que foi controlada através do coccidiostático Amprolbase (Lab. Farmabase Saúde Animal Ltda). Segundo Susin (2001), a infestação por Eimeria danifica a mucosa intestinal resultando em uma reduzida ou imprópria absorção de nutrientes o que pode levar a perda de peso. 
Tabela 13. Consumo de proteína bruta (CPB) dos cordeiros no período experimental.

\begin{tabular}{|c|c|c|c|c|c|c|}
\hline & \multicolumn{4}{|c|}{ Tratamentos $^{1}$} & \multirow[b]{2}{*}{$\mathrm{EPM}^{2}$} & \multirow[b]{2}{*}{$-P_{-}$} \\
\hline & T14 & T16 & T18 & T20 & & \\
\hline \multicolumn{7}{|c|}{ CPB, g/kg PV 0,75} \\
\hline Período 1 & $13,3^{d}$ & $14,7^{\mathrm{C}}$ & $17,9^{b}$ & $19,6^{\mathrm{a}}$ & 0,24 & 0,0001 \\
\hline Período 2 & $14,3^{\mathrm{C}}$ & $15,1^{\mathrm{C}}$ & $17,0^{\mathrm{b}}$ & $20,0^{a}$ & 0,47 & 0,0001 \\
\hline Média & $13,8^{c}$ & $14,8^{\mathrm{C}}$ & $17,8^{b}$ & $19,8^{a}$ & 0,31 & 0,0001 \\
\hline \multicolumn{7}{|l|}{ CPB, g/dia } \\
\hline Período 1 & $144,1^{b}$ & $161,4^{b}$ & $200,0^{a}$ & $219,5^{\mathrm{a}}$ & 4,82 & 0,0001 \\
\hline Período 2 & $185,9^{b}$ & $196,8^{b}$ & $237,0^{\mathrm{a}}$ & $266,3^{a}$ & 7,38 & 0,0001 \\
\hline Média & $165,0^{c}$ & $179,1^{c}$ & $218,5^{\mathrm{b}}$ & $242,9^{a}$ & 5,62 & 0,0001 \\
\hline
\end{tabular}

O aumento no consumo de proteína de PB decorrente do aumento no teor protéico da dieta também foi verificado por Beauchemin et al. (1995), Manso et al. (1998b) e Haddad et al. (2001). Beauchemin et al. (1995) verificaram consumo de PB de 170 e $205 \mathrm{~g} /$ dia para dietas com 15 e 18\% PB, respectivamente. Manso et al. (1998b), comparando dietas com 14 e 26\% PB, encontraram consumo de PB de $99 \mathrm{~g} / \mathrm{dia}$ ou $11,6 \mathrm{~g} / \mathrm{kg} \mathrm{PV}$,75 e $164 \mathrm{~g} / \mathrm{dia}$ ou $20,7 \mathrm{~g} / \mathrm{kg} \mathrm{PV}$ (0,75, respectivamente. Haddad et al. (2001) observaram que cordeiros alimentados com dietas com 16 e 18\% PB consumiram mais proteína (média de $187 \mathrm{~g} / \mathrm{dia}$ ) comparado com dietas com 12 e 14\% PB (média de 140 g/dia). 


\subsubsection{Rendimento de Carcaça}

Os dados referentes ao peso da carcaça quente, peso da carcaça fria, rendimento de carcaça quente, rendimento de carcaça fria e quebra por resfriamento estão apresentados na Tabela 14.

Observa-se que não houve diferença $(P>0,05)$ entre os tratamentos para peso da carcaça quente, peso da carcaça fria, rendimento de carcaça quente $(R C Q)$, rendimento de carcaça fria $(R C F)$ e quebra por resfriamento (QR). Esses resultados estão de acordo com os resultados obtidos por Beauchmin et al. (1995) e Zundt et al. (2001b), os quais não verificaram efeito de teores protéicos da dieta no rendimento da carcaça de cordeiros.

Com base em dados obtidos em frigoríficos e trabalhos de pesquisa, Silva Sobrinho (2001) sugeriu valores médios de $14,3 \mathrm{~kg}, 13,8 \mathrm{~kg}, 46 \%$ e $44,5 \%$ para peso da carcaça quente, peso da carcaça fria, rendimento de carcaça quente e rendimento de carcaça fria. Esses valores estão compatíveis com os resultados apresentados na Tabela 14, sugerindo que o presente experimento apresentou resultados satisfatórios para os parâmetros de avaliação de carcaça.

Tabela 14. Efeito dos teores de PB da dieta de cordeiros sobre alguns parâmetros de carcaça.

\begin{tabular}{|c|c|c|c|c|c|c|}
\hline \multicolumn{7}{|c|}{ Tratamentos $^{1}$} \\
\hline Parâmetros ${ }^{3}$ & T14 & T16 & T18 & T20 & $\mathrm{EPM}^{2}$ & $\mathrm{P}_{2}$ \\
\hline$\overline{P C Q}, \mathrm{~kg}$ & 14,8 & 14,6 & 15,1 & 15,6 & 0,36 & 0,25 \\
\hline $\mathrm{PCF}, \mathrm{kg}$ & 14,5 & 14,3 & 14,8 & 15,4 & 0,37 & 0,25 \\
\hline $\mathrm{RCQ}, \%$ & 44,5 & 44,1 & 44,5 & 44,9 & 0,49 & 0,76 \\
\hline $\mathrm{RCF}, \%$ & 43,5 & 43,2 & 43,6 & 44,0 & 0,50 & 0,76 \\
\hline QR, \% & 2,2 & 2,0 & 1,9 & 1,9 & 0,13 & 0,37 \\
\hline
\end{tabular}


O rendimento da carcaça após 24 horas em câmara fria a $2-4^{\circ} \mathrm{C}$ constitui-se um importante indicador da disponibilidade de carne ao consumidor (Silva Sobrinho, 2001), onde a diminuição das perdas por resfriamento tem papel chave na obtenção de melhores rendimentos. Baseando-se em dados obtidos em frigoríficos e trabalhos de pesquisa, Silva Sobrinho (2001) indica um valor médio de 4\% para QR. Monteiro et al. (1998), avaliando a substituição do milho pela polpa cítrica, encontraram valores de 3,5 a 5\% de QR para cordeiros mestiços Suffolk. Siqueira \& Fernandes (1999), utilizando dietas com 65\% de concentrado, verificaram valores de 3,54 e $2,83 \%$ de QR para cordeiros Corriedale e mestiços, respectivamente. Observa-se que os valores encontrados no presente trabalho para QR (média de $2 \%$ ) foram inferiores aos citados acima. Isso pode ter ocorrido devido a uma maior deposição de gordura na carcaça, em decorrência da utilização de uma dieta com alta proporção de concentrado, ocasionando, assim, menores perdas por desidratação durante o resfriamento.

\subsubsection{Nitrogênio uréico plasmático (NUP)}

Os dados resultantes da concentração de nitrogênio uréico plasmático estão apresentados na Tabela 15.

Os tratamentos com teores de PB maiores resultaram em maiores $(P<0,05)$ concentrações de NUP. Antes do fornecimento das dietas $(0 \mathrm{~h})$, as concentrações de NUP dos animais nos tratamentos com 18 e $20 \%$ PB foram maiores do que para os tratamentos com 14 e 16\% PB. Entretanto, após 3 horas do fornecimento das dietas, apenas os animais no tratamento com $14 \%$ PB apresentaram concentrações de NUP inferiores aos animais nos demais tratamentos.

Hatfield et al. (1998) observaram que cordeiros alimentados com dietas contendo 18\% PB tiveram uma maior concentração de NUP do que cordeiros 
alimentados com dietas contendo 10\% PB, cujos valores foram 24,2 e 13,0 mg/ $100 \mathrm{ml}$, respectivamente.

O aumento da concentração de nitrogênio uréico plasmático decorrente do aumento na concentração protéica da dieta é causado pelo aumento da absorção de amônia ruminal, resultando em maiores quantidades de amônia sendo utilizadas no fígado para formar uréia. Dessa forma, a concentração de nitrogênio uréico no sangue reflete a ingestão de proteína dietária (Thomas et al., 1988). Bunting et al. (1987) verificaram que a porcentagem de NUP derivado da absorção de amônia ruminal foi maior para cordeiros alimentados com dietas contendo $15,4 \%$ PB em comparação a cordeiros alimentados com $8,7 \%$ PB (16,5 e 6,1\%, respectivamente). Os mesmos autores verificaram concentrações de NUP de 2,9 e 12,9 mg/ $100 \mathrm{ml}$ para as dietas com $8,7 \mathrm{e}$ $15,4 \%$ PB

Tabela 15. Efeito dos teores de PB da dieta na concentração de uréia plasmática $(\mathrm{mg} / 100 \mathrm{ml})$

\begin{tabular}{|c|c|c|c|c|c|c|}
\hline \multirow[b]{2}{*}{ horas após alimentação } & \multicolumn{4}{|c|}{ Tratamentos $^{1}$} & \multirow[b]{2}{*}{$\mathrm{EPM}^{2}$} & \multirow[b]{2}{*}{${ }_{-} P_{-}$} \\
\hline & T14 & T16 & T18 & T20 & & \\
\hline 0 & $18,4^{c}$ & $23,3^{b}$ & $28,8^{a}$ & $29,5^{a}$ & 1,67 & 0,001 \\
\hline 3 & $21,4^{b}$ & $27,4^{\mathrm{a}}$ & $29,5^{a}$ & $30,8^{a}$ & 1,40 & 0,002 \\
\hline
\end{tabular}

Beauchemin et al. (1995) também verificaram que o aumento da proporção de PB, em dietas altamente energéticas, de 15 para $18 \%$ aumentou as concentrações de NUP de 12,9 para $18,6 \mathrm{mg} / 100 \mathrm{ml}$, sendo que esse efeito remanesceu até o final do experimento. Entretanto, esses valores foram inferiores aos encontrados neste experimento.

Sultan \& Loerch (1992) verificaram que a concentração de NUP foi maior às 4 horas em cordeiros alimentados com maior teor protéico, observando 
valores de 10,5 e 17,5 mg/100 ml para as dietas com 9,5 e 12,5\% PB, respectivamente.

\subsection{Experimento II: Digestibilidade dos Nutrientes}

\subsubsection{Digestibilidade e Consumo de Matéria Seca e Matéria Orgânica}

Os resultados referentes ao consumo e digestibilidade da MS e MO estão apresentados na Tabela 16. Não houve efeito $(P>0,05)$ de tratamentos sobre o consumo e digestibilidade aparente da MS e da MO.

O consumo de matéria seca dos animais foi em média 48,8 g/ kg PV 0,75 . Esse valor foi inferior aos encontrados por Bunting et al. (1987) e Zeoula et al. (1999) os quais observaram consumos de 86,4 e $65,5 \mathrm{~g} / \mathrm{kg} \mathrm{PV}$ (0,75, respectivamente. Por outro lado foi próximo aos verificados por Hussein et al. (1991) e Lallo (1996), os quais observaram consumos de 51,0 e $47,0 \mathrm{~g} / \mathrm{kg}$ $\mathrm{PV}^{0,75}$, respectivamente.

As digestibilidades aparentes da MS e MO não diferiram entre os tratamentos, com valores médios de 75,2 e 76,8 \%, respectivamente. Esses resultados estão de acordo com os encontrados por Zundt et al. (2001c), os quais verificaram que os crescentes níveis protéicos (12 a 24\% PB) não influenciaram a digestibilidade da matéria seca e orgânica $(77,76$ e 80,9\%, respectivamente). Outros autores obtiveram resultados semelhantes, observando médias de 63,9 e 65,7\% na digestibilidade da MS e MO, respectivamente, para dietas com 9 e 12\% PB e $68 \%$ de concentrado na MS (Sultan \& Loerch, 1992). Já em outro estudo, utilizando dietas com $78 \%$ de concentrado e concentrações protéicas entre 10 e 18\% PB, verificou-se médias de coeficientes de digestibilidade para MS e MO de 70 e $74 \%$, respectivamente (Haddad et al., 2001). 
Tabela 16. Efeito da concentração protéica da dieta sobre a digestibilidade aparente da matéria seca e matéria orgânica no trato total de ovinos.

\begin{tabular}{|c|c|c|c|c|c|c|c|}
\hline \multirow[b]{2}{*}{ Item $^{2}$} & \multicolumn{5}{|c|}{ Tratamentos $^{1}$} & \multirow[b]{2}{*}{$\mathrm{EPM}^{3}$} & \multirow[b]{2}{*}{$--\mathrm{P}--$} \\
\hline & T12 & T14 & T16 & T18 & T20 & & \\
\hline CMS (kg/d) & 0,83 & 0,87 & 0,98 & 0,79 & 0,82 & 0,07 & 0,377 \\
\hline CMS (g/ kg PV ${ }^{0,75}$ ) & 47,8 & 49,6 & 54,8 & 45,0 & 47,0 & 3,80 & 0,486 \\
\hline \multicolumn{8}{|c|}{ Digestibilidade Aparente MS } \\
\hline$\%$ & 73,9 & 72,1 & 74,5 & 78,6 & 77,0 & 2,73 & 0,514 \\
\hline $\mathrm{kg} / \mathrm{d}$ & 0,62 & 0,60 & 0,72 & 0,63 & 0,64 & 0,05 & 0,556 \\
\hline $\mathrm{CMO}(\mathrm{kg} / \mathrm{d})$ & 0,75 & 0,77 & 0,88 & 0,66 & 0,71 & 0,06 & 0,240 \\
\hline $\mathrm{CMO}\left(\mathrm{g} / \mathrm{kg} \mathrm{PV} \mathrm{V}^{0,75}\right)$ & 42,9 & 43,6 & 49,1 & 37,5 & 40,1 & 3,71 & 0,297 \\
\hline \multicolumn{8}{|c|}{ Digestibilidade Aparente MO } \\
\hline$\%$ & 75,2 & 73,6 & 75,7 & 80,5 & 79,0 & 2,82 & 0,438 \\
\hline $\mathrm{kg} / \mathrm{d}$ & 0,57 & 0,54 & 0,66 & 0,53 & 0,58 & 0,05 & 0,407 \\
\hline
\end{tabular}

\subsubsection{Digestibilidade, consumo e Balanço de N}

Os resultados referentes ao consumo, digestibilidade e balanço de $\mathrm{N}$ estão apresentados na Tabela 17.

O consumo e a digestibilidade aparente do $\mathrm{N}$ e PB foram maiores $(\mathrm{P}<0,05)$ para as dietas com 16, 18 e 20\% PB em relação às dietas com 12 e $14 \%$ PB. Vários trabalhos têm verificado aumento na digestibilidade do $\mathrm{N}$ com o aumento do teor de N da dieta (Sultan \& Loerch, 1992; Beauchmin et al, 1995; Lallo, 1996; Manso et al., 1998b; Haddad et al., 2001 e Zundt et al., 2001c). Owens \& Zinn (1988) verificaram que a regressão da digestibilidade de $\mathrm{N}$ contra a ingestão de $\mathrm{N}$ produz uma linha reta ao longo de uma grande variedade de dietas, de modo a concluir que a digestibilidade aparente de $\mathrm{N}$ varia com o teor de $\mathrm{N}$ da dieta. De acordo com Stallcup et al. (1975), esse fato 
pode ser atribuído à maior ingestão de $\mathrm{N}$, concomitante à progressiva diminuição da proporção de $\mathrm{N}$ endógeno nos compostos nitrogenados fecais.

Sultan \& Loerch (1992) observaram que a digestibilidade aparente do $\mathrm{N}$ foi maior para dietas com 12,5\% PB do que para dietas com 9,5\% $(69,2$ e $62,0 \%$, respectivamente). Haddad et al. (2001) encontraram coeficiente de digestibilidade aparente entre 74,2 e $76,6 \%$ para dietas variando de 12 a $18 \%$. Zundt et al. (2001c), trabalhando com níveis protéicos na dieta de 12 a 24\% PB, verificaram que os níveis protéicos crescentes aumentaram os valores de digestibilidade da proteína bruta de 78,56 para $86,53 \%$. Estes coeficientes de digestibilidade aparente apresentados são similares aos encontrados nesse experimento.

Não houve efeito $(P>0,05)$ de tratamento para a quantidade de $N$ excretado nas fezes, entretanto, o aumento no teor de PB da dieta levou a um aumento $(P<0,05)$ na excreção de $N$ urinário. Rogério et al. (2001) verificaram um aumento na excreção de $\mathrm{N}$ na urina quando a concentração protéica da dieta variou de 7,8 a 16\%. Entretanto, os mesmos autores não verificaram variação no nitrogênio fecal metabólico. Esses resultados foram similares aos encontrados por Bunting et al. (1987), Sultan \& Loerch (1992) e Valadares et al. (1997a). O aumento do $\mathrm{N}$ urinário evidenciado pode ser explicado com base em estudos de Van Soest (1994), segundo os quais, altos consumos de nitrogênio e rápida digestão ruminal deste nutriente resultam em produção de amônia acima das necessidades microbianas, a qual é absorvida pela corrente sanguínea, convertida em uréia no fígado e excretada na urina.

A retenção de $N$ quando expressa em $g /$ dia foi maior $(P<0,05)$ para as dietas com 16, 18 e 20\% PB em relação às dietas com 12 e 14\% PB. Entretanto, a retenção de $\mathrm{N}$ quando expressa em \% do $\mathrm{N}$ digerido e do $\mathrm{N}$ consumido foi maior $(\mathrm{P}<0,05)$ para as dietas com 16 e 18\% em relação àdieta com 14\%, não diferindo das dietas com 12 e $20 \%$ PB. 
Tabela 17. Efeito da concentração protéica da dieta sobre a digestibilidade e metabolismo de $\mathrm{N}$ em ovinos.

\begin{tabular}{|c|c|c|c|c|c|c|c|}
\hline \multirow[b]{2}{*}{ Item $^{2}$} & \multicolumn{5}{|c|}{ Tratamentos $^{1}$} & \multirow[b]{2}{*}{$\mathrm{EPM}^{3}$} & \multirow[b]{2}{*}{$--P--$} \\
\hline & T12 & T14 & T16 & T18 & T20 & & \\
\hline CPB (g/d) & $105,0^{b}$ & $125,4^{a b}$ & $157,1^{\mathrm{a}}$ & $143,7^{\mathrm{ab}}$ & $167,6^{\mathrm{a}}$ & 10,6 & 0,009 \\
\hline CPB (g/ kg PV $\left.{ }^{0,75}\right)$ & $5,98^{\mathrm{b}}$ & $7,17^{\mathrm{ab}}$ & $8,82^{\mathrm{a}}$ & $8,15^{\mathrm{ab}}$ & $9,49^{a}$ & 0,61 & 0,012 \\
\hline $\mathrm{CN}(\mathrm{g} / \mathrm{d})$ & $16,8^{b}$ & $20,1^{\mathrm{ab}}$ & $25,1^{a}$ & $23,0^{a b}$ & $26,8^{a}$ & 1,69 & 0,009 \\
\hline$N$ fezes $(g / d)$ & 4,5 & 5,9 & 5,9 & 3,9 & 4,7 & 0,93 & 0,480 \\
\hline$N$ urina $(g / d)$ & $7,7^{\mathrm{c}}$ & $11,0^{b}$ & $10,7^{\mathrm{b}}$ & $11,7^{b}$ & $14,0^{\mathrm{a}}$ & 0,84 & 0,003 \\
\hline \multicolumn{8}{|c|}{ Digestibilidade aparente N } \\
\hline$\%$ & $72,7^{b}$ & $73,3^{b}$ & $77,3^{a b}$ & $82,7^{\mathrm{a}}$ & $82,5^{\mathrm{a}}$ & 2,23 & 0,016 \\
\hline$g / d$ & $12,3^{b}$ & $14,1^{b}$ & $19,2^{a}$ & $19,1^{\mathrm{a}}$ & $22,2^{\mathrm{a}}$ & 1,54 & 0,003 \\
\hline \multicolumn{8}{|l|}{ Balanço de N } \\
\hline$g / d$ & $4,5^{\mathrm{b}}$ & $3,1^{b}$ & $8,5^{\mathrm{a}}$ & $7,4^{\mathrm{a}}$ & $8,1^{\mathrm{a}}$ & 1,62 & 0,048 \\
\hline$\% \mathrm{~N}$ consumido & $24,3^{a b}$ & $16,3^{b}$ & $33,1^{a}$ & $31,3^{a}$ & $26,6^{\mathrm{ab}}$ & 4,78 & 0,046 \\
\hline$\%$ N digerido & $32,1^{\mathrm{ab}}$ & $21,8^{b}$ & $38,9^{a}$ & $37,8^{a}$ & $32,3^{\mathrm{ab}}$ & 5,03 & 0,043 \\
\hline
\end{tabular}

Segundo Owens \& Zinn (1988), a retenção de $N$ serve como uma estimativa da deposição de proteína para fatores produtivos (leite, tecido, lã) mais os não-produtivos (pele, cabelo). Dessa maneira, a ausência de resposta em ganho de peso apresentada na Tabela 11, pode ser explicada, em parte, pela retenção de $\mathrm{N}$ apresentada na Tabela 15, uma vez que não houve aumento na retenção de $\mathrm{N}$ ( $\mathrm{g} / \mathrm{dia}$ ) para dietas com teores de PB acima de $16 \%$.

Sultan \& Loerch (1992) observaram um aumento de 9\% na retenção de $\mathrm{N}$ (porcentagem do $\mathrm{N}$ ingerido) para dietas com 12,5\% PB em comparação a dietas com 9,5\% PB (47,8 e 52,1 \%, respectivamente). A retenção de N (g/dia) também foi maior para a dieta com $12,5 \%(7,43)$ do que para a com $9,5 \%$ 
$(5,28)$. Bunting et al. (1987) também verificaram que cordeiros alimentados com dieta com maior teor protéico $(15,4 \% \mathrm{~PB})$ retiveram uma maior quantidade de $\mathrm{N}$ em comparação aos alimentados com dieta com menor teor protéico ( $8,7 \% \mathrm{~PB})$, onde foram obtidos 9,7 e 4,1 g/dia, respectivamente, assim como a utilização do $\mathrm{N}$ como uma proporção do $\mathrm{N}$ ingerido foi maior para a dieta com maior teor protéico $(45,7$ e $34,1 \%$, respectivamente).

\subsubsection{Digestibilidade e Consumo da Fibra em Detergente Neutro (FDN), da Fibra em Detergente Ácido (FDA) e do Extrato Etéreo (EE)}

Os resultados referentes ao consumo e digestibilidade de FDN, FDA e EE estão apresentados na Tabela 18, onde se verifica que não houve efeito $(P>0,05)$ de tratamentos sobre o consumo e digestibilidade aparente da FDN e FDA.

Haddad et al. (2001) encontraram digestibilidades aparentes similares da FDN e FDA para dietas variando de 12 a $18 \%$ de PB. Esses resultados foram similares aos encontrados por Bunting et al. (1987), Manso et al. (1998b) e Mulligan et al. (2001).

O consumo e a digestibilidade aparente expressa em $\mathrm{g} / \mathrm{dia}$ de extrato etéreo foi maior $(P<0,05)$ para o tratamento com $16 \%$ PB em relação ao tratamento com 20\% PB, não diferindo $(P>0,05)$ do tratamento com 12, 14 e $18 \%$ PB. Não houve efeito $(P>0,05)$ de tratamentos sobre a digestibilidade aparente do EE (Tabela 18). 
Tabela 18. Efeito da concentração protéica da dieta sobre a digestibilidade aparente da FDN e FDA no trato total de ovinos.

\begin{tabular}{|c|c|c|c|c|c|c|c|}
\hline \multirow[b]{2}{*}{ Item $^{2}$} & \multicolumn{6}{|c|}{ Tratamentos $^{1}$} & \multirow[b]{2}{*}{$--P--$} \\
\hline & T12 & T14 & T16 & T18 & T20 & $\mathrm{EPM}^{3}$ & \\
\hline CFDN (g/d) & 271,8 & 293,5 & 331,9 & 268,8 & 273,5 & 28,34 & 0,508 \\
\hline \multicolumn{8}{|c|}{ Digestibilidade aparente FDN } \\
\hline$\%$ & 53,1 & 53,1 & 57,4 & 68,3 & 64,8 & 5,82 & 0,691 \\
\hline$g / d$ & 147,7 & 141,5 & 188,4 & 186,5 & 176,1 & 29,21 & 0,287 \\
\hline CFDA (g/d) & 173,0 & 206,6 & 225,1 & 185,1 & 188,9 & 19,40 & 0,406 \\
\hline \multicolumn{8}{|c|}{ Digestibilidade aparente FDA } \\
\hline$\%$ & 51,6 & 55,8 & 57,3 & 66,3 & 63,6 & 5,81 & 0,665 \\
\hline$g / d$ & 92,5 & 105,7 & 127,9 & 126,9 & 120,3 & 19,58 & 0,394 \\
\hline CEE (g/dia) & $33,6^{\mathrm{ab}}$ & $32,1^{\mathrm{ab}}$ & $41,8^{\mathrm{a}}$ & $29,6^{\mathrm{ab}}$ & $27,7^{\mathrm{b}}$ & 2,79 & 0,031 \\
\hline \multicolumn{8}{|c|}{ Digestibilidade aparente EE } \\
\hline$\%$ & 83,6 & 82,3 & 83,9 & 78,8 & 81,9 & 3,08 & 0,779 \\
\hline$g / d$ & $28,8^{\mathrm{ab}}$ & $26,4^{\mathrm{ab}}$ & $34,6^{a}$ & $24,2^{\mathrm{ab}}$ & $23,1^{b}$ & 2,52 & 0,049 \\
\hline
\end{tabular}

${ }^{1}$ Porcentagem de proteína bruta na matéria seca das dietas.

${ }^{2}$ CFDN= consumo de fibra insolúvel em detergente neutro, CFDA= consumo de fibra insolúvel em detergente ácido, $\mathrm{CEE}=$ consumo de extrato etéreo

${ }^{3}$ Erro padrão da média.

Zundt et al. (2001c), trabalhando com dietas contendo níveis protéicos de 12 a $24 \%$ PB, verificaram que a digestibilidade do EE e do FDN apresentaram efeito quadrático, sendo que o nível protéico de $16,5 \%$ foi o que proporcionou o valor mais alto de digestibilidade do EE (83,83\%), enquanto que o nível de $17,8 \%$ proporcionou a menor digestibilidade da FDN $(52,2 \%)$. 


\subsubsection{Parâmetros Ruminais}

\subsubsection{Valores de $\mathrm{pH}$}

Os dados resultantes da leitura de $\mathrm{pH}$ ruminal estão apresentados na Tabela 19. A Figura 1 ilustra a variação de pH ruminal, mostrando variações similares entre os tratamentos durante o transcorrer do dia.

Não houve diferença $(P>0,05)$ entre os valores médios diários de $\mathrm{pH}$ de cada tratamento (parcelas), assim como não houve efeito $(P>0,05)$ na interação tratamento e horário de coleta. Porém verificou-se diferença $(\mathrm{P}<0,05)$ ao longo do dia (subparcelas).

Tabela 19. Efeito da concentração protéica da dieta sobre o pH ruminal de cordeiros

\begin{tabular}{ccccccc}
\hline & \multicolumn{4}{c}{ Tratamentos $^{1}$} & subparcelas $^{4}$ \\
\cline { 2 - 5 } Horário $^{2}, \mathrm{~h}$ & $\mathrm{~T} 12$ & $\mathrm{~T} 14$ & $\mathrm{~T} 16$ & $\mathrm{~T} 18$ & $\mathrm{~T} 20$ & $\mathrm{P}<0,05$ \\
\hline 0 & 6,79 & 6,75 & 6,94 & 6,73 & 6,95 & $6,83^{\mathrm{A}}$ \\
2 & 6,51 & 6,56 & 6,56 & 6,49 & 6,67 & $6,56^{\mathrm{B}}$ \\
4 & 6,06 & 6,45 & 6,12 & 6,17 & 6,34 & $6,23^{\mathrm{C}}$ \\
6 & 5,82 & 6,25 & 5,94 & 6,00 & 6,12 & $6,03^{\mathrm{D}}$ \\
8 & 5,73 & 6,17 & 5,95 & 5,87 & 5,98 & $5,94^{\mathrm{E}}$ \\
10 & 5,83 & 6,20 & 5,88 & 5,97 & 6,02 & $5,98^{\mathrm{DE}}$ \\
12 & 5,84 & 5,94 & 5,94 & 6,02 & 6,02 & $5,95^{\mathrm{DE}}$ \\
Parcelas $^{3}$ & 6,08 & 6,33 & 6,19 & 6,18 & 6,30 &
\end{tabular}

${ }^{1}$ Porcentagem de proteína bruta na matéria seca das dietas. ${ }^{2}$ Horário de coleta: tempo após o fornecimento da dieta. ${ }^{3}$ Média das parcelas (tratamentos) $\mathrm{P}>0,05 .{ }^{4}$ Média das subparcelas (horários de coleta).

${ }^{A B}$ Médias na mesma coluna seguidas de letras distintas diferem entre si a 5\% de significância. 


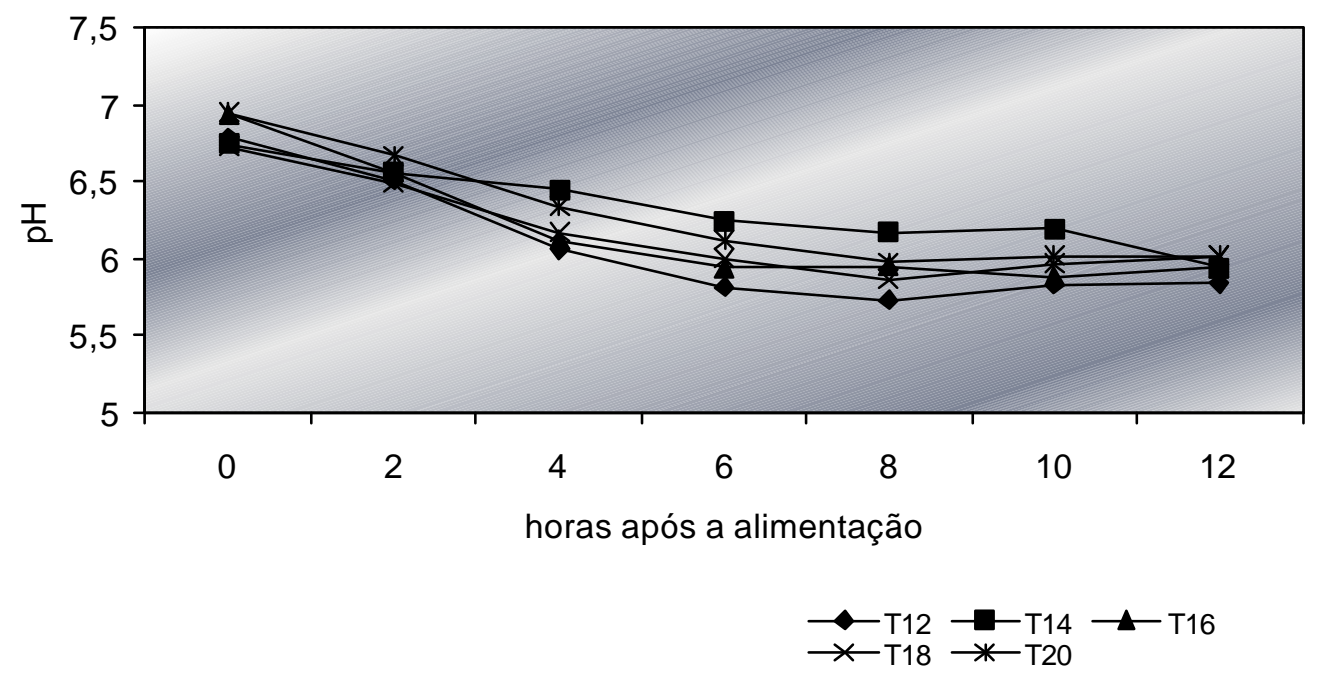

Figura 1- Valores de $\mathrm{pH}$ ruminal durante 12 horas após o fornecimento das dietas

$\mathrm{O} \mathrm{pH}$ variou $(\mathrm{P}<0,05)$ entre os valores médios de cada horário de coleta (subparcelas) e teve seus maiores valores médios no momento anterior ao fornecimento do alimento (média de 6,83). Os menores valores ocorreram 8 horas após o fornecimento da dieta.

Valadares et al. (1997b), utilizando dietas com 45\% de concentrado e teores de PB variando de 7,0 a 14,5\% para novilhos zebu, observaram valores de pH entre 6,27 a 7,09, sendo que o pH mínimo foi obtido 9,59 horas após a alimentação. Já Hatfield et al. (1998), utilizando dietas com $35 \%$ de concentrado, verificaram que cordeiros alimentados com 18\% PB tiveram pH ruminal menor do que cordeiros alimentados com $10 \%$ PB, sendo que os menores valores de $\mathrm{pH}(6,2$ e 6,3) foram obtidos entre 2 a 4 horas após 0 fornecimento da dieta.

Owens \& Goetsch (1988) sugeriram que, para dietas com alta proporção de concentrado, espera-se valores de $\mathrm{pH}$ entre 5,5 e 6,5. No presente trabalho, a faixa de variação do $\mathrm{pH}$ média observada foi de 5,94 a 6,83. Zeoula et al. 
(1999) encontraram valores de $\mathrm{pH}$ entre 6,05 e 7,21 para dietas com $65 \%$ de concentrado. Susin et al. (1995) verificaram valores de pH entre 5,36 e 5,92 para dietas com $90 \%$ de concentrado e entre 5,8 e 6,9 para dietas com $20 \%$ de concentrado. Já Hart \& Glimp (1991) observaram valores médios de pH de 6,$13 ; 5,85$ e 5,61 para dietas contendo $55,72,5$ e $90 \%$ de concentrado, respectivamente.

\section{2.4.2 Concentração de nitrogênio amoniacal no rúmen}

Os dados resultantes da análise de concentração do $\mathrm{N}$ amoniacal no rúmen estão apresentados na Tabela 20. A Figura 2 ilustra a variação durante o dia da concentração de $\mathrm{N}$ amoniacal no líquido ruminal de acordo com os tratamentos.

$\mathrm{O}$ valor médio observado na concentração de $\mathrm{N}$ amoniacal no rúmen no momento do fornecimento da alimentação foi $22,38 \mathrm{mg} / 100 \mathrm{ml}$. O pico na concentração de $\mathrm{N}$ amoniacal no rúmen ocorreu 2 horas após o fornecimento da dieta para os tratamentos com 12, 14, 16 e 18\% PB e 4 horas para o tratamento com 20\% PB. Esse fato pode ter sido decorrente da maior quantidade de farelo de soja contida na dieta com $20 \%$ PB, fazendo com que houvesse uma maior contribuição proporcionalmente do $\mathrm{N}$ proveniente do farelo de soja em relação ao $\mathrm{N}$ proveniente da uréia e cloreto de amônio (nitrogênio não protéico). Segundo Owens \& Zinn (1988), quando a fonte de nitrogênio predominante é uréia (ou outra fonte de nitrogênio não protéico), o pico da concentração de amônia ruminal ocorre 1 a 2 horas após a alimentação. Entretanto, quando a fonte de nitrogênio predominante é proveniente de proteína vegetal o pico da concentração de amônia ruminal ocorre 3 a 5 horas após a alimentação.

Houve efeito $(P<0,05)$ na interação tratamento $x$ horário de coleta. Não houve efeito de tratamento $(P>0,05)$ para os tempos 0,8 e 12 horas após o fornecimento das dietas. 
As dietas que continham teores maiores de PB na MS levaram os animais a produzirem uma maior $(\mathrm{P}<0,05)$ concentração ruminal de $\mathrm{N}$ amoniacal, provavelmente pelo fato do consumo de PB pelos animais submetidos a esses tratamentos ter sido maior, conforme mostrado na Tabela 18.

Mehrez \& Orskov, citados por Zeoula et al. (1999), estimaram que a concentração mínima de amônia deve ser de $23 \mathrm{mg} / 100 \mathrm{ml}$ de líquido ruminal para se obter taxa máxima de fermentação ruminal para ovinos recebendo concentrado. Leng \& Nolan (1984), entretanto, sugerem que concentrações acima de $5-10 \mathrm{mg} / 100 \mathrm{ml}$ no líquido ruminal não tem aumentado a produção de proteína microbiana, embora a concentração de amônia exigida para o ótimo crescimento microbiano ainda não seja bem estabelecida.

$\mathrm{O}$ aumento da concentração ruminal de $\mathrm{N}$ amoniacal, em função do teor de PB da dieta foi verificado por Faria \& Huber (1984), Rihani et al. (1993), Cruz Souto et al. (1994) e Valadares et al. (1997b).

Valadares et al. (1997b), utilizando dietas com teores de PB variando de 7,0 a $14,5 \%$ para novilhos zebu, obtiveram concentrações máximas e mínimas de $\mathrm{N}$ amoniacal æ̀̀ 1,92 e 9,37 horas após o fornecimento das dietas, respectivamente.

Segundo Sultan \& Loerch (1992), a concentração de N-NH 3 no rúmen foi maior æ̀ 4 horas após alimentação para cordeiros com maior teor protéico, a qual foi 8,0 e $20,2 \mathrm{mg} / 100 \mathrm{ml}$ para as dietas com 9,5 e 12,5\% PB, respectivamente. Para Zeoula et al. (1999), os picos das concentrações $\mathrm{N}-\mathrm{NH}_{3}$ do líquido ruminal ocorreram 2 horas após alimentação, variando de 16 a 36,3 $\mathrm{mg} / 100 \mathrm{ml}$. 
Tabela 20. Efeito da concentração protéica da dieta sobre a concentração de nitrogênio amoniacal no rúmen $(\mathrm{mg} / 100 \mathrm{ml})$

\begin{tabular}{|c|c|c|c|c|c|c|}
\hline \multirow[b]{2}{*}{ Horário $^{2}, \mathrm{~h}$} & \multicolumn{5}{|c|}{ Tratamentos $^{1}$} & \multirow{2}{*}{$\begin{array}{c}\text { subparcelas }^{4} \\
P<0,05\end{array}$} \\
\hline & T12 & T14 & $\mathrm{T} 16$ & T18 & T20 & \\
\hline 0 & ${ }^{B} 20,3$ & $\mathrm{~B}_{17,1}$ & $\mathrm{~B}_{17,3}$ & ${ }^{B} 30,8$ & $\mathrm{CB}_{26,3}$ & $22,3^{C}$ \\
\hline 2 & ${ }^{A} 40,6^{b}$ & ${ }^{A} 30,8^{b}$ & ${ }^{A} 34,9^{b}$ & ${ }^{A} 52,2^{a}$ & ${ }^{\mathrm{B}} 35,6^{\mathrm{b}}$ & $38,8^{A}$ \\
\hline 4 & $\mathrm{~B}_{20,2^{\mathrm{b}}}$ & $\mathrm{AB}_{24,8^{\mathrm{b}}}$ & $\mathrm{B}_{14,1^{\mathrm{b}}}$ & $\mathrm{AB}_{42,5^{\mathrm{a}}}$ & ${ }^{\mathrm{A}} 46,8^{\mathrm{a}}$ & $29,7^{\mathrm{B}}$ \\
\hline 6 & $\mathrm{~B}_{12,4^{\mathrm{a}}}$ & $\mathrm{AB}_{20}, 3^{\mathrm{b}}$ & $\mathrm{B}_{17,3^{\mathrm{b}}}$ & ${ }^{\mathrm{B}} 35,7^{\mathrm{a}}$ & ${ }^{\mathrm{B}} 36,1^{\mathrm{a}}$ & $24,4^{\mathrm{C}}$ \\
\hline 8 & ${ }^{B} 9,5$ & $\mathrm{~B}_{15,9}$ & $\mathrm{~B}_{16,0}$ & $c_{25,2}$ & $\mathrm{C}_{20,5}$ & $17,4^{\mathrm{D}}$ \\
\hline 10 & $\mathrm{~B}_{10,2^{\mathrm{b}}}$ & $\mathrm{B}_{11,3^{\mathrm{b}}}$ & $\mathrm{B}_{18,3^{\mathrm{ab}}}$ & $\mathrm{C}_{24,0^{\mathrm{a}}}$ & $\mathrm{c}_{24,1^{\mathrm{a}}}$ & $17,6^{\mathrm{D}}$ \\
\hline 12 & $\mathrm{~B}_{11,9}$ & $\mathrm{~B}_{12,3}$ & $\mathrm{~B}_{14,6}$ & $\mathrm{C}_{22,8}$ & $c_{23,8}$ & $17,1^{\mathrm{D}}$ \\
\hline Parcelas $^{3}$ & $17,9^{b}$ & $18,9^{b}$ & $18,9^{b}$ & $33,3^{\mathrm{a}}$ & $30,4^{a}$ & \\
\hline
\end{tabular}

\footnotetext{
${ }^{1}$ Porcentagem de proteína bruta na matéria seca das dietas. ${ }^{2}$ Horário de coleta: tempo após o fornecimento da dieta. ${ }^{3}$ Média das parcelas (tratamentos) $\mathrm{P}<0,05 .{ }^{4}$ Média das subparcelas (tempos).

${ }^{A B}$ Médias na mesma coluna seguidas de letras distintas diferem entre si a $5 \%$ de significância.

${ }^{\mathrm{ab}}$ Médias na mesma linha seguidas de letras distintas diferem entre si a 5\% de significância.
}

Os dados do presente experimento indicam que os tratamentos que geraram maiores concentrações de amônia ruminal tiveram esse efeito refletido na concentração de uréia plasmática, concordando com Kennedy \& Milligan (1980), os quais verificaram uma forte correlação positiva entre concentração de uréia plasmática e concentração de amônia ruminal. Em resumo, os altos níveis de $\mathrm{N}$ urinário (Tabela 18) indicaram altos consumos de nitrogênio inorgânico ou de proteína de rápida digestão ruminal, resultando em produção de amônia acima das necessidades microbianas. A amônia em excesso foi absorvida pela corrente sangüínea, convertida em uréia no fígado e excretada na urina. Segundo Arieli (1994), estas altas perdas urinárias de nitrogênio com aumentos na produção de uréia podem ser dispendiosos para o organismo animal em termos de produção de calor metabólico. 


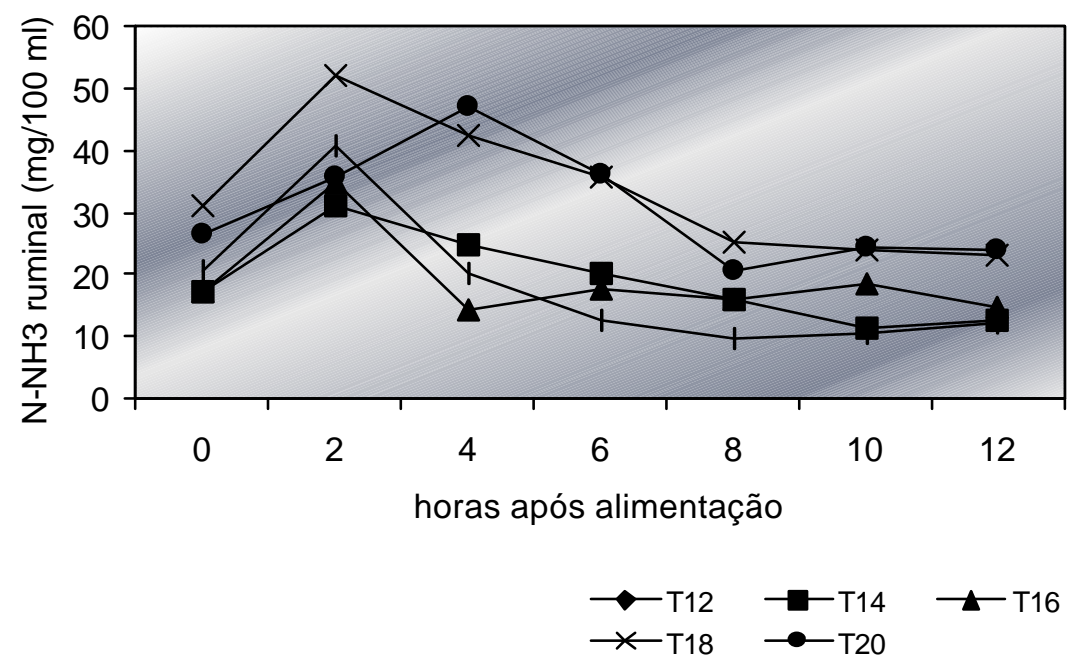

Figura 2 - Concentração de nitrogênio amoniacal no rúmen durante 12 horas após o fornecimento das dietas.

\subsubsection{3 Ácidos Graxos Voláteis Totais}

Os dados resultantes da análise da concentração molar de ácidos graxos voláteis (AGV) totais no rúmen estão apresentados na Tabela 21. A Figura 3 ilustra a variação durante o dia na concentração total de ácidos graxos voláteis no líquido ruminal de acordo com os tratamentos.

Não houve diferença $(P>0,05)$ na interação tratamento $x$ horário de coleta e nos valores médios diários da concentração molar de AGV totais de cada tratamento (parcelas), sugerindo que tais dietas permitiram uma fermentação similar da matéria orgânica pelos microrganismos ruminais, uma vez que a concentração dos AGV no líquido ruminal sofre maior influência da degradabilidade ruminal da MO do que da PB (Arieli et al., 1996). 
Tabela 21. Efeito da concentração protéica da dieta sobre a concentração de ácidos graxos voláteis totais $(\mathrm{mM})$ no fluido ruminal

\begin{tabular}{ccccccc}
\hline & \multicolumn{5}{c}{ Tratamentos $^{1}$} & subparcela $^{4}$ \\
\cline { 2 - 5 } Horário $^{2}, \mathrm{~h}$ & $\mathrm{~T} 12$ & $\mathrm{~T} 14$ & $\mathrm{~T} 16$ & $\mathrm{~T} 18$ & $\mathrm{~T} 20$ & $\mathrm{P}<0,05$ \\
\hline 0 & 57,7 & 69,7 & 64,7 & 85,8 & 52,4 & $66,1^{\mathrm{C}}$ \\
2 & 61,6 & 72,7 & 63,4 & 74,5 & 60,6 & $66,6^{\mathrm{C}}$ \\
4 & 87,8 & 70,8 & 84,2 & 91,7 & 82,7 & $83,4^{\mathrm{B}}$ \\
6 & 92,4 & 78,1 & 100,1 & 103,7 & 95,1 & $93,9^{\mathrm{B}}$ \\
8 & 132,78 & 98,7 & 123,1 & 120,0 & 119,3 & $119,7^{\mathrm{A}}$ \\
10 & 127,6 & 118,7 & 139,2 & 105,4 & 122,0 & $122,6^{\mathrm{A}}$ \\
12 & 109,9 & 107,2 & 116,9 & 107,1 & 126,4 & $113,5^{\mathrm{A}}$ \\
Parcelas $^{3}$ & 95,7 & 88,0 & 98,8 & 98,3 & 94,1 &
\end{tabular}

\footnotetext{
1 Porcentagem de proteína bruta na matéria seca das dietas. ${ }^{2}$ Horário de coleta: tempo após o fornecimento da dieta. ${ }^{3}$ Média das parcelas (tratamentos) $\mathrm{P}>0,05 .{ }^{4}$ Média das subparcelas (tempos).

${ }^{\mathrm{AB}}$ Médias na mesma coluna seguidas de letras distintas diferem entre si a $5 \%$ de significância.
}

A concentração total de AGV no líquido ruminal variou $(\mathrm{P}<0,05)$ entre os valores médios de cada horário de coleta (subparcelas). No momento do fornecimento da dieta, observou-se concentração média de $66,10 \mathrm{mM}$, sendo que o maior acúmulo de AGV ocorreu em torno de 10 horas após o fornecimento da dieta (122 mM). Hussein et al. (1991) observaram uma concentração de AGV totais de $92,5 \mathrm{mM}$ em cordeiros alimentados com uma dieta com $65 \%$ concentrado e $15,5 \%$ PB. Susin et al. (1995) verificaram concentração de AGV totais entre 78,9 mM e 129,3 mM (entre 0 e 12 horas após alimentação) para cordeiros alimentados com uma dieta com 90\% concentrado e $19 \%$ PB. 


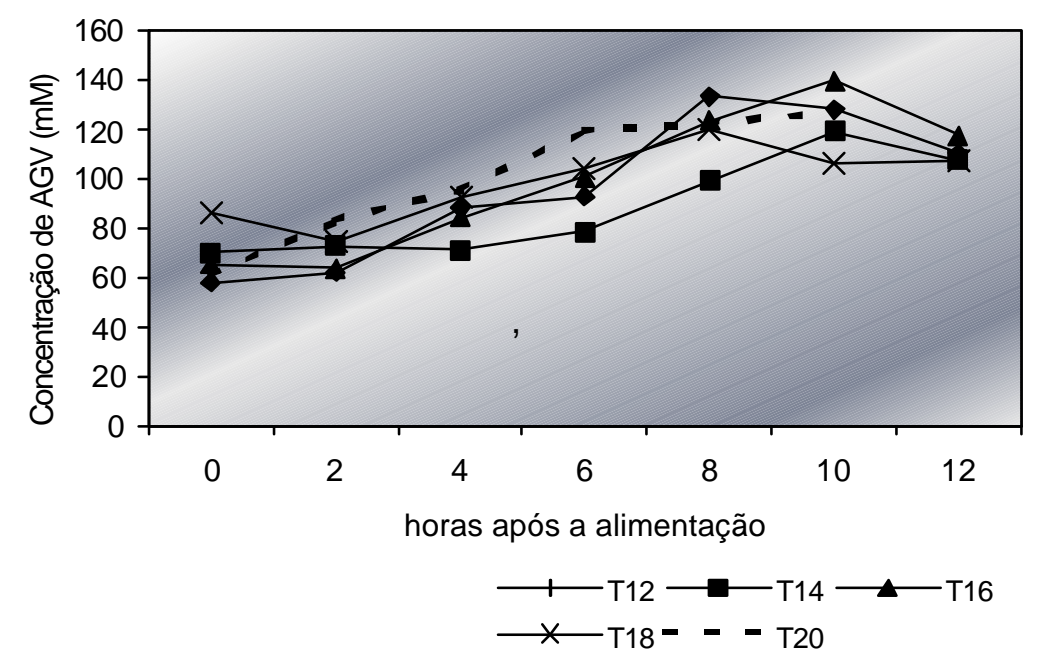

Figura 3 - Concentração total de ácidos graxos voláteis no rúmen durante 12 horas após o fornecimento das dietas.

\subsubsection{4 Ácido Acético}

Os dados resultantes da análise da concentração molar de ácido acético e a sua variação durante o dia no líquido ruminal estão apresentados na Tabela 22 e Figura 4.

Não houve diferença $(P>0,05)$ na interação tratamento $x$ horário de coleta. Os valores médios diários da concentração molar de ácido acético de cada tratamento (parcelas) não diferiram entre si $(P>0,05)$.

A concentração molar de ácido acético no líquido ruminal variou $(P<0,05)$ entre os valores médios de cada horário de coleta (subparcelas). No momento de fornecimento da dieta, observou-se concentração média de 32,04 mM, sendo que o maior acúmulo ocorreu em torno de 10 horas após o fornecimento da dieta. 
Hussein et al. (1991) observaram uma concentração de ácido acético de $60,6 \mathrm{mM}$ em cordeiros alimentados com uma dieta com $65 \%$ concentrado e $15,5 \%$ PB. Susin et al. (1995) verificaram concentração de ácido acético entre 33,8 mM e 54,5 mM durante 12 horas após alimentação para cordeiros alimentados com uma dieta com 90\% concentrado e 19\% PB. Entretanto, Hatfield et al. (1998) verificaram concentrações maiores para dietas com $18 \%$ em relação às dietas com 10\% PB (57,2 e 46,6 mM, respectivamente).

Tabela 22. Efeito da concentração protéica da dieta sobre a concentração de ácido acético $(\mathrm{mM})$ no fluido ruminal.

\begin{tabular}{ccccccc}
\hline & \multicolumn{5}{c}{ Tratamentos $^{1}$} & subparcelas $^{4}$ \\
\cline { 2 - 5 } Horário $^{2}, \mathrm{~h}$ & $\mathrm{~T} 12$ & $\mathrm{~T} 14$ & $\mathrm{~T} 16$ & $\mathrm{~T} 18$ & $\mathrm{~T} 20$ & $\mathrm{P}<0,05$ \\
\hline 0 & 35,1 & 44,1 & 40,7 & 55,6 & 32,0 & $32,0^{\mathrm{CB}}$ \\
2 & 36,9 & 45,6 & 37,4 & 47,2 & 35,2 & $40,4^{\mathrm{C}}$ \\
4 & 49,8 & 43,3 & 47,2 & 57,3 & 49,4 & $49,4^{\mathrm{B}}$ \\
6 & 51,5 & 47,2 & 56,3 & 65,6 & 55,7 & $55,3^{\mathrm{B}}$ \\
8 & 76,4 & 60,8 & 67,6 & 74,5 & 69,3 & $69,7^{\mathrm{A}}$ \\
10 & 72,9 & 72,1 & 77,2 & 65,7 & 70,0 & $70,0^{\mathrm{A}}$ \\
12 & 61,5 & 64,2 & 62,8 & 65,9 & 71,5 & $65,2^{\mathrm{A}}$ \\
Parcelas $^{3}$ & 54,9 & 53,9 & 55,6 & 61,7 & 54,7 &
\end{tabular}

${ }^{1}$ Porcentagem de proteína bruta na matéria seca da dieta. ${ }^{2}$ Horário de coleta: tempo após o fornecimento da dieta. ${ }^{3}$ Média das parcelas (tratamentos) P $>0,05 .{ }^{4}$ Média das subparcelas (tempos).

${ }^{A B C}$ Médias na mesma coluna seguidas de letras distintas diferem entre si a $5 \%$ de significância. 


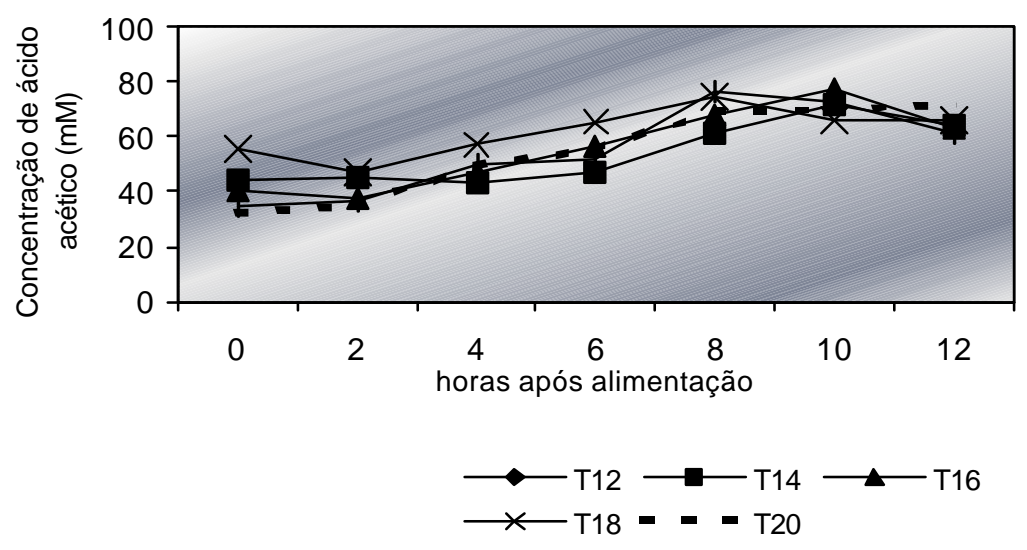

Figura 4 - Concentração de ácido acético no rúmen durante 12 horas após o fornecimento das dietas.

\subsubsection{5 Ácido Propiônico}

Os dados resultantes da análise da concentração molar de ácido propiônico e a sua variação durante o dia no líquido ruminal estão apresentados na Tabela 23 e Figura 5.

Não houve diferença $(P<0,05)$ na interação tratamento $x$ horário para a concentração molar de ácido propiônico. Os valores médios diários da concentração molar de ácido propiônico de cada tratamento (parcelas) não diferiram entre si $(P>0,05)$.

A concentração molar de ácido propiônico no líquido ruminal variou $(P<0,05)$ entre os valores médios de cada horário de coleta (subparcelas). No momento de fornecimento da dieta, observou-se concentração média de 12,94 $\mathrm{mM}$, sendo que o maior acúmulo ocorreu em torno de 8 a 10 horas após o fornecimento da dieta.

Hussein et al. (1991) observaram uma concentração de ácido propiônico de $18,3 \mathrm{mM}$ em cordeiros alimentados com uma dieta com $65 \%$ concentrado e 15,5\% PB. Susin et al. (1995) verificaram concentração de ácido propiônico entre $37,4 \mathrm{mM}$ e $60,5 \mathrm{mM}$ durante 12 horas após alimentação para cordeiros 
alimentados com uma dieta com 90\% concentrado e 19\% PB. Entretanto, Hatfield et al. (1998) verificaram concentrações maiores para dietas com $18 \%$ em relação \&̀ dietas com 10\% PB (14,5 e 11,5 mM, respectivamente). Observa-se que os valores da concentração de ácido propiônico encontrados nesse trabalho (Tabela 23) foram divergentes dos apresentados na literatura, o que pode ser devido a diferenças nos ingredientes das dietas.

Tabela 23. Efeito da concentração protéica da dieta sobre a concentração de ácido propiônico (mM) no fluido ruminal.

\begin{tabular}{ccccccc}
\hline & \multicolumn{5}{c}{ Tratamentos $^{1}$} & subparcelas $^{4}$ \\
$n_{\text {Horário }}{ }^{2}, \mathrm{~h}$ & $\mathrm{~T} 12$ & $\mathrm{~T} 14$ & $\mathrm{~T} 16$ & $\mathrm{~T} 18$ & $\mathrm{~T} 20$ & $\mathrm{P}<0,05$ \\
\hline 0 & 11,6 & 13,6 & 11,6 & 17,2 & 10,5 & $12,9^{\mathrm{C}}$ \\
2 & 14,9 & 17,1 & 15,6 & 16,2 & 14,5 & $15,6^{\mathrm{C}}$ \\
4 & 24,6 & 18,4 & 23,6 & 21,5 & 19,9 & $21,6^{\mathrm{B}}$ \\
6 & 25,8 & 21,0 & 27,9 & 23,8 & 24,1 & $24,5^{\mathrm{B}}$ \\
8 & 35,8 & 25,7 & 35,5 & 28,5 & 30,7 & $31,2^{\mathrm{A}}$ \\
10 & 34,4 & 32,2 & 38,0 & 23,6 & 30,4 & $31,7^{\mathrm{A}}$ \\
12 & 30,5 & 29,5 & 34,1 & 24,7 & 31,3 & $30,1^{\mathrm{A}}$ \\
Parcelas $^{3}$ & 25,4 & 22,5 & 26,6 & 22,2 & 23,0 &
\end{tabular}

Torcentagem de proteína bruta na matéria seca das dietas. ${ }^{2}$ Horário de coleta: tempo após o fornecimento da dieta. ${ }^{3}$ Média das parcelas (tratamentos) $\mathrm{P}>0,05 .{ }^{4}$ Média das subparcelas (tempos).

${ }^{A B C}$ Médias na mesma coluna seguidas de letras distintas diferem entre si a $5 \%$ de significância. 

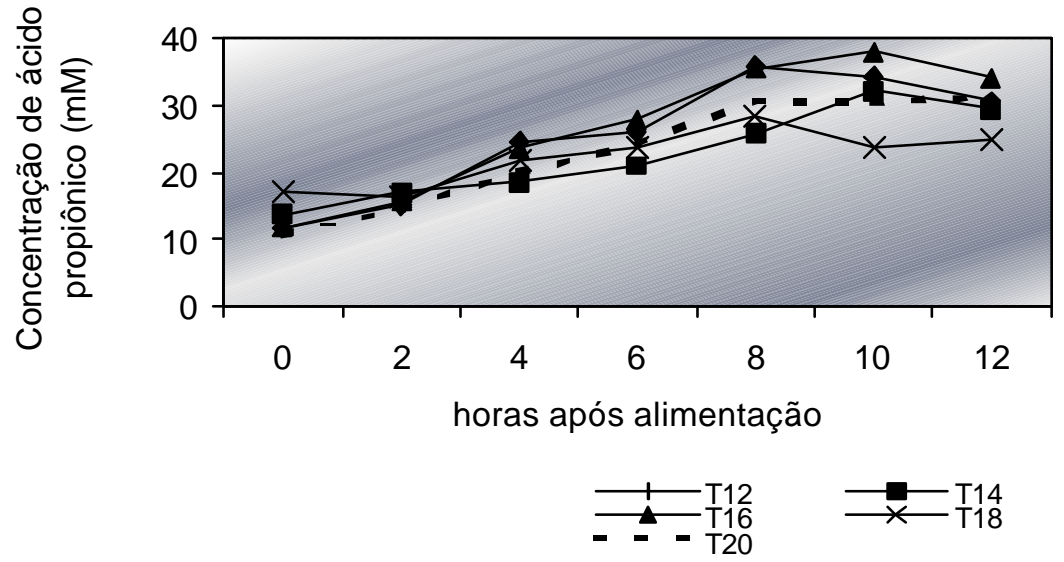

Figura 5 - Concentração de ácido propiônico no rúmen durante 12 horas após o fornecimento das dietas.

\subsubsection{6 Ácido Butírico}

Os dados resultantes da análise da concentração molar de ácido butírico e a sua variação durante o dia no líquido ruminal estão apresentados na Tabela 24 e Figura 6.

Não houve diferença $(P<0,05)$ na interação tratamento $x$ horário de coleta para a concentração molar de ácido butírico. Os valores médios diários da concentração molar de ácido butírico foram maiores $(\mathrm{P}<0,05)$ para os tratamentos com 12, 16 e 20\% PB em relação ao tratamento com 14\% PB, não diferindo $(P>0,05)$ do tratamento com 18\% PB.

A concentração molar de ácido butírico no líquido ruminal variou $(P<0,05)$ entre os valores médios de cada horário de coleta (subparcelas). No momento de fornecimento da dieta, observou-se concentração média de 7,06 mM, sendo que o maior acúmulo ocorreu em torno de 8 a 10 horas após o fornecimento da dieta. 
Tabela 24. Efeito da concentração protéica da dieta sobre a concentração de ácido butírico (mM) no fluido ruminal.

\begin{tabular}{ccccccc}
\hline & \multicolumn{5}{c}{ Tratamentos $^{1}$} & subparcelas $^{4}$ \\
\cline { 2 - 5 } Horário $^{2}, \mathrm{~h}$ & $\mathrm{~T} 12$ & $\mathrm{~T} 14$ & $\mathrm{~T} 16$ & $\mathrm{~T} 18$ & $\mathrm{~T} 20$ & $\mathrm{P}<0,05$ \\
\hline 0 & 6,9 & 7,9 & 7,3 & 6,9 & 6,1 & $7,1^{\mathrm{D}}$ \\
2 & 6,6 & 6,5 & 6,9 & 6,7 & 7,6 & $6,9^{\mathrm{D}}$ \\
4 & 10,4 & 6,2 & 10,1 & 8,6 & 9,5 & $8,9^{\mathrm{C}}$ \\
6 & 12,0 & 7,0 & 12,3 & 10,2 & 11,4 & $10,5^{\mathrm{B}}$ \\
8 & 16,4 & 8,8 & 15,6 & 12,3 & 14,8 & $13,6^{\mathrm{A}}$ \\
10 & 16,4 & 10,6 & 19,1 & 11,9 & 16,4 & $14,9^{\mathrm{A}}$ \\
12 & 14,2 & 9,9 & 15,7 & 12,2 & 17,8 & $13,9^{\mathrm{A}}$ \\
Parcelas $^{3}$ & $11,8^{\mathrm{a}}$ & $8,2^{\mathrm{b}}$ & $12,4^{\mathrm{a}}$ & $9,8^{\mathrm{ab}}$ & $11,9^{\mathrm{a}}$ &
\end{tabular}

\footnotetext{
1 Porcentagem de proteína bruta na matéria seca das dietas. ${ }^{2}$ Horário de coleta: tempo após o fornecimento da dieta. ${ }^{3}$ Média das parcelas (tratamentos) $\mathrm{P}<0,05 .{ }^{4}$ Média das subparcelas (tempos).

${ }^{A B C}$ Médias na mesma coluna seguidas de letras distintas diferem entre si a $5 \%$ de significância.

${ }^{a b c}$ Médias na mesma linha seguidas de letras distintas diferem entre si a 5\% de significância.
}

Hussein et al. (1991) observaram uma concentração de ácido butírico de 9,62 mM em cordeiros alimentados com uma dieta com $65 \%$ concentrado e 15,5\% PB. Hatfield et al. (1998) verificaram concentrações maiores para dietas com 18\% em relação à dietas com 10\% PB (9,2 e 6,8 mM, respectivamente). Ambos os valores foram inferiores aos encontrados nesse experimento (Tabela 24). 


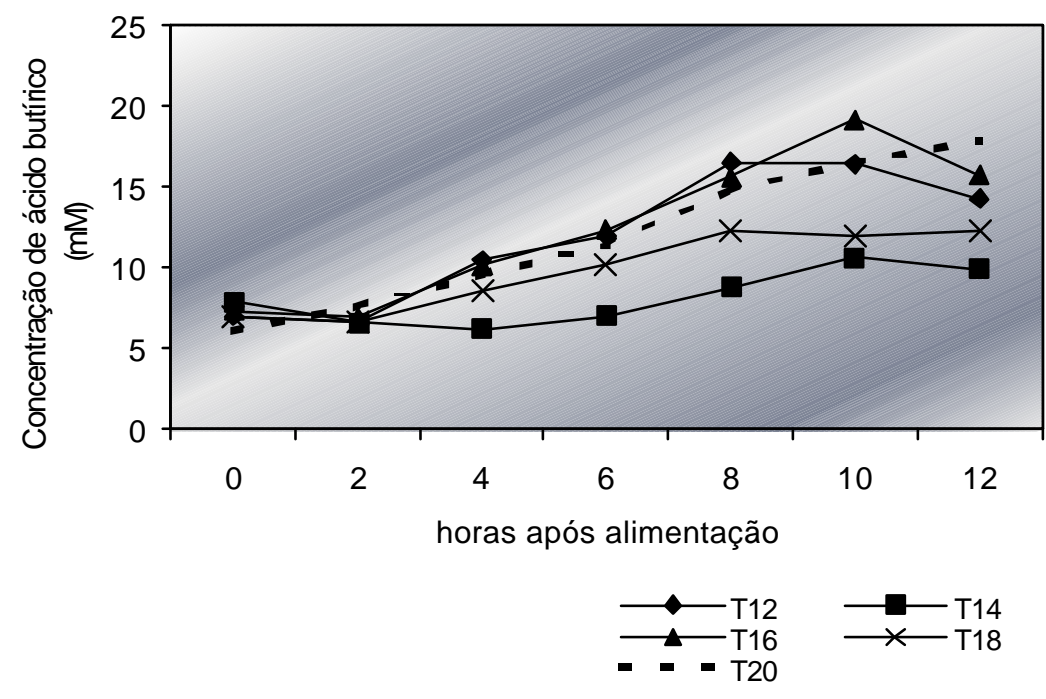

Figura 6 - Concentração de ácido butírico no rúmen durante 12 horas após o fornecimento das dietas.

\subsubsection{Relação Acetato/Propionato}

Os dados referentes à análise da relação acetato/propionato estão apresentados na Tabela 25 e Figura 7. Não houve interação $(P>0,05)$ tratamento $\mathrm{x}$ horário de coletas para a relação acetato/propionato.

Houve efeito $(P<0,05)$ do horário de coleta (subparcelas) sobre a relação acetato/propionato no fluido ruminal, com o valor mais elevado ocorrendo no momento do fornecimento da dieta e os valores mais baixos ocorrendo a partir das 4 horas. Esse fato pode ter sido decorrente da queda concomitante do $\mathrm{pH}$ (Tabela 19) para valores abaixo de 6,0, podendo estar prejudicando a digestão da fibra. Yokoyama \& Johnson (1988) citam que bactérias celulolíticas e bactérias metanogênicas são severamente afetadas quando $\mathrm{pH}$ ruminal cai abaixo de 6,0. Lykos et al. (1997) observaram que a relação acetato/propionato diminuiu de 3,12 para 2,60 quando o $\mathrm{pH}$ ruminal caiu de 6,43 para 6,19.

Não foi observada diferença $(P>0,05)$ na relação acetato/propionato entre os valores médios diários de cada tratamento (parcelas). 
Tabela 25. Efeito da concentração protéica da dieta sobre a relação acetato/propionato no fluido ruminal.

\begin{tabular}{|c|c|c|c|c|c|c|}
\hline \multirow[b]{2}{*}{ Horário $^{2}, \mathrm{~h}$} & \multicolumn{5}{|c|}{ Tratamentos $^{1}$} & \multirow{2}{*}{$\begin{array}{c}\text { subparcelas }^{4} \\
\text { P }<0,05\end{array}$} \\
\hline & T12 & $\mathrm{T} 14$ & $\mathrm{~T} 16$ & $\mathrm{~T} 18$ & T20 & \\
\hline 0 & 3,01 & 3,32 & 3,40 & 3,63 & 3,14 & $3,32^{A}$ \\
\hline 2 & 2,72 & 2,81 & 2,85 & 3,03 & 2,55 & $2,75^{\mathrm{B}}$ \\
\hline 4 & 2,38 & 2,56 & 2,54 & 2,80 & 2,52 & $2,58^{\mathrm{C}}$ \\
\hline 6 & 2,25 & 2,50 & 2,54 & 2,81 & 2,37 & $2,49^{C}$ \\
\hline 8 & 2,20 & 2,47 & 2,58 & 2,77 & 2,32 & $2,47^{\mathrm{C}}$ \\
\hline 10 & 2,34 & 2,56 & 2,53 & 2,83 & 2,35 & $2,52^{C}$ \\
\hline 12 & 2,23 & 2,49 & 2,50 & 2,76 & 2,32 & $2,46^{\mathrm{C}}$ \\
\hline Parcelas ${ }^{3}$ & 2,46 & 2,67 & 2,67 & 2,95 & 2,51 & \\
\hline
\end{tabular}

De acordo com Fahey \& Berger (1988), a relação acetato: propionato é dependente da relação forragem: concentrado da dieta. Em geral, assim que a relação forragem: concentrado diminui, a razão acetato: propionato diminui. Os mesmos autores sugerem como aceitável, por exemplo, uma relação de acetato: propionato de 2,2 para dietas com alta proporção de concentrado. Uma vez que todas as dietas desse experimento tinham a mesma relação forragem: concentrado (20:80), é esperado que todas as dietas apresentassem a mesma relação acetato: propionato. Hart \& Glimp (1991) utilizando dieta com 90\% de concentrado encontraram um valor de 1,69 para relação acetato: propionato. Já Hussein et al. (1991) utilizando dieta com $65 \%$ de concentrado encontraram um valor de 3,3 para relação acetato: propionato. 


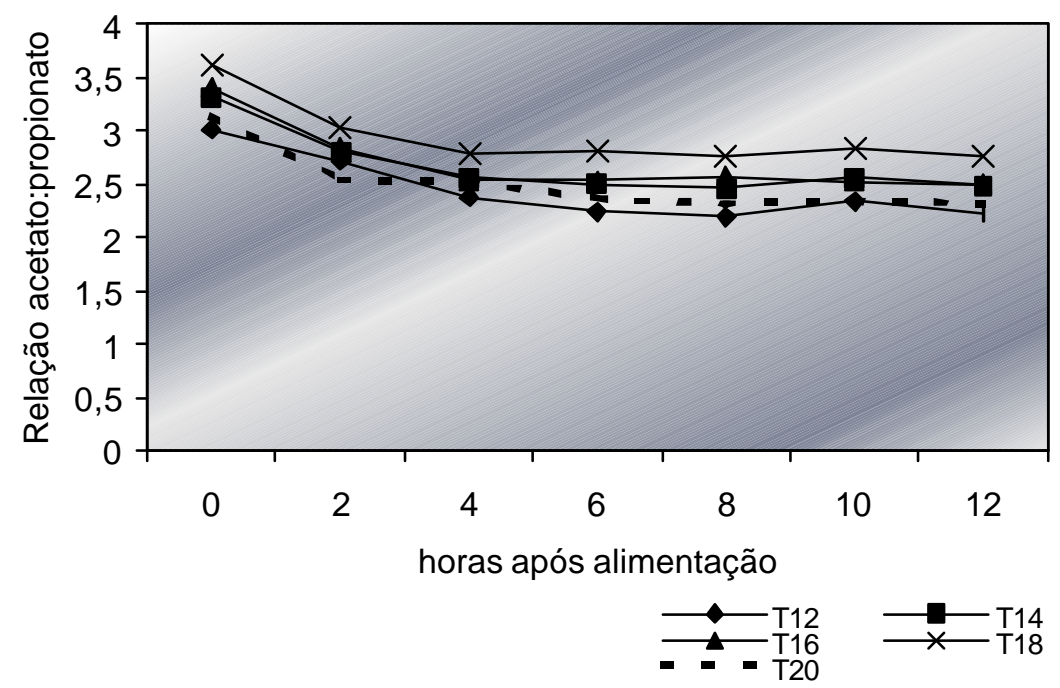

Figura 7 - Relação acetato/propionato no rúmen durante 12 horas após o fornecimento das dietas.

\subsubsection{Proporção molar média dos ácidos graxos voláteis no rúmen}

Os dados referentes à porcentagem molar dos ácidos acético, propiônico, butírico, valérico, isobutírico e isovalérico em relação ao total de AGV no rúmen estão apresentados na Tabela 26.

Não houve diferença $(P>0,05)$ na proporção molar dos ácidos propiônico, valérico e isovalérico entre os tratamentos.

A diferença $(P<0,05)$ na proporção molar do ácido butírico entre os tratamentos foi reflexo da concentração molar média apresentada na Tabela 24. 
Tabela 26. Proporção molar média (\%) dos ácidos graxos voláteis em relação ao total de AGV no rúmen.

\begin{tabular}{lccccccc}
\hline & \multicolumn{7}{c}{ Tratamentos $^{1}$} \\
ácido & $\mathrm{T} 12$ & $\mathrm{~T} 14$ & $\mathrm{~T} 16$ & $\mathrm{~T} 18$ & $\mathrm{~T} 20$ & EPM $^{2}$ & --P-- \\
\hline acético & $57,75^{\mathrm{b}}$ & $61,71^{\mathrm{ab}}$ & $57,37^{\mathrm{b}}$ & $62,97^{\mathrm{a}}$ & $58,60^{\mathrm{ab}}$ & 2,41 & 0,037 \\
propiônico & 25,56 & 25,09 & 25,45 & 22,23 & 24,12 & 2,83 & 0,715 \\
butírico & $12,70^{\mathrm{a}}$ & $9,20^{\mathrm{b}}$ & $12,62^{\mathrm{a}}$ & $10,16^{\mathrm{ab}}$ & $12,42^{\mathrm{a}}$ & 1,16 & 0,034 \\
valérico & 1,17 & 1,07 & 1,33 & 1,38 & 1,28 & 0,15 & 0,616 \\
isobutírico & $0,82^{\mathrm{b}}$ & $0,84^{\mathrm{b}}$ & $0,92^{\mathrm{b}}$ & $1,03^{\mathrm{ab}}$ & $1,29^{\mathrm{a}}$ & 0,12 & 0,036 \\
isovalérico & 1,99 & 2,08 & 2,31 & 2,23 & 2,29 & 0,40 & 0,811 \\
\hline
\end{tabular}

Em relação à porcentagem molar do ácido acético, observa-se que o tratamento com $18 \%$ PB apresentou maior $(\mathrm{P}<0,05)$ porcentagem molar em relação aos tratamentos com 12 e 16\% PB, não diferindo $(P>0,05)$ dos tratamentos com 14 e 20\% PB. Já a proporção molar do ácido isobutírico foi maior $(P<0,05)$ para o tratamento com $20 \% \mathrm{~PB}$ em relação aos tratamentos com 12, 14 e 16\% PB, não diferindo do tratamento com 18\% PB.

De modo geral, o aumento do teor de PB da dieta favoreceu uma maior porcentagem de ácido butírico e isobutírico em detrimento de ácido acético.

Bergman (1990) cita, para ovinos alimentados com alta proporção de grãos na dieta, uma proporção molar de AGV de 53, 34 e 13\% para os ácidos acético, propiônico e butírico, respectivamente, sendo que o ácido valérico e outros de cadeia carbônica maior geralmente apresentam valores menores do que $5 \%$ do total. 


\section{CONCLUSÕES}

Os dados de desempenho e metabolismo do presente estudo indicam que as recomendações do NRC (1985a) para teores de proteína bruta na dieta de cordeiros em crescimento (16\%) são adequadas, uma vez que teores acima de $16 \%$ resultam em perdas de $\mathrm{N}$ via urina sem melhora no desempenho animal.

Dietas com alta proporção de concentrado (80\%), utilizando bagaço de cana-de-açúcar hidrolisado e in natura, podem proporcionar um ambiente ruminal adequado, com valores de $\mathrm{pH}$ e concentrações de ácidos graxos voláteis satisfatórios para um bom desempenho animal. 


\section{REFERÊNCIAS BIBLIOGRÁFICAS}

AGRICULTURAL RESEARCH COUNCIL. The nutrient requirements of ruminant livestock. London: Commonwealth Agricultural Bureaux, 1980. $351 \mathrm{p}$.

AMARANTE, A. F. T. Controle de endoparasitoses dos ovinos. In: REUNIÃO ANUAL DA SOCIEDADE BRASILEIRA DE ZOOTECNIA, 38., Piracicaba, 2001. A produção animal na visão dos brasileiros. Piracicaba: FEALQ, 2001. p.461-473.

ANDREWS, R. P.; ORSKOV, E. R. The nutrition of the early weaned lamb. 2. The effect of dietary protein concentration, feeding level and sex on body composition at two live weigths. Journal of Agricultural Science, v. 75, p.19-26, 1970.

ARIELI, A. Effectof whole cottonseed on patitioning of energy and nitrogen balance in sheep. Animal Production, v. 58, n.1, p.103-108, 1994.

ARIELI, A.; SHABI, Z.; BRUCKENTAL, I.; TAGARI, H.; AHARONI, Y.; ZAMWEL, S.; VOET, H. Effect of degradation of organic matter and crude protein on ruminal fermentation in dairy cows. Journal of Dairy Science, v.79, p.1774, 1996.

ARSENOS, G.; KYRIAZAKIS, I. Does previous protein feeding affect the response of sheep towards foods that differ in their rúmen availability, but not content, of nitrogen? Physiology and Behavior, v.72, p.533-541, 2001 ASSOCIATION OF OFFICIAL ANALYTICAL CHEMISTS. Official methods of analysis. 12.ed. Washinton, 1990. 1015p. 
BARROS, N. N.; SIMPLíCIO, A. A.; BARBIERI, M. E. Desempenho de borregos das raças Santa Inês e Somalis Brasileira, em prova de ganho de peso. In: REUNIÃO ANUAL DA SOCIEDADE BRAZILEIRA DE ZOOTECNIA, 33., Fortaleza, 1996. Anais. Fortaleza: SBZ, 1996. p.258-259.

BEAUCHMIN, K. A.; McCLELLAND, L. A.; JONES, S. D. M.; KOZUB, G. C. Effects of crude protein content, protein degradability and energy concentration of the diet on growth and carcass characteristics of market lambs fed high concentrate diets. Canadian Journal of Animal Science, v.75, p.387-395, 1995.

BERGMAN, E. N. Energy contribuitions of volatile fatty acids from the gastrointestinal tract in various species. Physiological Review, v.70, n.2, p.567-590, 1990.

BUNTING, L. D.; BOLING, J. A.; MACKOWN, C. T.; MUNTIFERING, R. B. Effect of dietary protein level on nitrogen metabolism in lambs: studies using ${ }^{15} \mathrm{~N}$-Nitrogen. Journal of Animal Science, v.64, p.855-867, 1987.

BURGI, R. Produção de bagaço de cana-de-açúcar auto-hidrolisado e avaliação do seu valor nutritivo para ruminantes. Piracicaba, 1985. 123p Dissertação (Mestrado) - Escola Superior de Agricultura 'Luiz de Queiroz', Universidade de São Paulo.

CHOWDHURY, S. A.; ORSKOV, E. R. Protein energy relationships with particular references to energy undernutrition : A review. Small Ruminant Research, v.26, p.1-7, 1997.

CHANEY, A. L.; MARBACH, E. P. Modified reagents for determination of urea and amonia. Clinical Chemistry, v.8, p. 130-137, 1962.

COSTA, C. A. F.; VIEIRA, L. S.; PANT, K. P. Valores de eritrócitos e eosinófilos em cordeiros deslanados, antes e depois de medicações anti-helmínticas. Pesquisa Agropecuária Brasileira, v.21, n.2, p.193-201, fev. 1986. 
CRUZ SOUTO, R.; MUHAMMED, S. A.; NEWBOLD, C. J. Influence of peptides, amino acids and urea on microbial activity in the rúmen of sheep receiving grass hay and on growth of rúmen bactéria in vitro. Animal Feed Science and Technology, v.49, n.1/2, p.151-161, 1994.

FAHEY Jr., G. C.; BERGER, L. L. Carbohydrate nutrition of ruminants. In: $\mathrm{CHURCH}, \mathrm{D}$. C. The ruminant animal. Englewood Cliffs: Waveland Press, 1988. cap.14, p.269-297.

FARIA, V. P.; HUBER, J. T. Effect of dietary protein and energy levels on rúmen fermentation in holtein steers. Journal of Animal Science, v.58, n.2, p.452459, 1984.

FIGUEIREDO, E. A.P.; SHELTON, M.; BARBIERI, M.E. Available genetic resources: the origin and classification of the world's sheep. In: SHELTON, M.; FIGUEIREDO, E. A.P. Hair sheep production in tropical and subtropical regions. Davis: Small Ruminant Collaborative Research Support Program, 1990. cap.2, p.7-24.

FLUHARTY, F. L.; McCLURE, K. E. Effect of dietary energy intakes and protein concentration on performance and visceral organ mass in lambs. Journal of Animal Science, v.75, p.604-610, 1997.

GARCIA, I. F. F.; PEREZ, J. R. O.; BONAGURIO, S.; SOUZA, X. R.; PEDREIRA, B. C.; ASSIS, R. M. Desempenho de cordeiros Santa Inês com Texel, lle de France e Bergamácia. In: REUNIÃO ANUAL DA SOCIEDADE BRASILEIRA DE ZOOTECNIA, 38., Piracicaba, 2001. Anais. Piracicaba: FEALQ, 2001. p.1144-1146.

GASTALDI, K. A.; SILVA SOBRINHO, A. G. Desempenho de ovinos F1 Ideal $x$ lle de France em confinamento com diferentes relações concentrado : volumoso (compact disc). In: REUNIÃO ANUAL DA SOCIEDADE BRASILEIRA DE ZOOTECNIA, 35., Botucatu, 1998. Anais. Botucatu: SBZ, 1998. 
GOERING, H. K.; VAN SOEST, P. J. Forage fiber analyses (apparatus, reagents, procedures, and some applications). Agricultural Handbook, n. 379. Washington, USDA-ARS, 1970.

GOETSCH, A. L. Growing and finishing performance by lambs differing in growth potencial consuming diets during growing varying in levels of corn and rumen undegradable protein. Small Ruminant Research , v.31, p.245257, 1999.

HADDAD, S. G.; NASR, R. E.; MUWALLA, M. M. Optimum dietary crude protein level for finishing Awassi lambs. Small Ruminant Research , v.39, p. 41-46, 2001.

HART, S. P.; GLIMP, H. A. Effect of diet composition and feed intake level on diet digestibility and ruminal metabolism in growing lambs. Journal of Animal Science, v.69, p.1636-1644, 1991.

HATFIELD, P. G.; HOPKINS, J.A.; RAMSEY, W. S.; GILMORE, A. Effects of level of protein and type of molasses on digesta kinetics and blood metabolites in sheep. Small Ruminant Research , v.28, p.161-170, 1998.

HOOVER, W. H.; STOKES, S. R. Balancing carbohydrates and proteins for optimum rumen microbial yield. Journal of Dairy Science, v. 74, p.36303641, 1991.

HUSSEIN, H. S.; JORDAN, R. M.; STERN, M. D. Ruminal protein metabolism and intestinal amino acid utilization as affected by dietary protein and carbohydrate sources in sheep. Journal of Animal Science, v.69, p. 21342146, 1991.

JORDAN, R. M.; MARTEN, G. C. Effect of weaning, age of weaning and grain feeding on the performance and production of grazing lambs. Journal of Animal Science, v.27, p. 174-180, 1968.

KENNEDY, P. M.; MILLIGAN, L. P. The degradation and utilization of endogenous urea in the gastro intestinal tract of ruminants: a review. Canadian Journal of Animal Science, v.60, p.205, 1980. 
LALLO, C. H. O. Feed intake and nitrogen utilisation by growing goats fed byproduct based diets of different protein and energy levels. Small Ruminant Research, v.22, p.193-204, 1996.

LENG, R. A.; NOLAN, J. V. Nitrogen metabolism in the rúmen. Journal of Dairy Science. Symposium: protein nutrition of the lactating dairy cow, v.67, p.1027-1089, 1984.

LYKOS, T.; VARGA, G. A.; CASPER, D. Varying degradation rates of total nonstructural carbohydrates: effects on ruminal fermentation, blood metabolites, and milk production and composition in high producing holstein cows, Journal of Dairy Science. v.80, p.3341-3355, 1997.

MANSO, T.; MANTECÒN, A. R.; GIRALDEZ, F. J.; LAVIN, P.; CASTRO, T. Animal performance and chemical body composition of lambs fed diets with different protein supplements. Small Ruminant Research , v.29, p.185-191, 1998a.

MANSO, T.; MANTECÓN, A. R.; CASTRO, T.; IASON, G. R. Effect of intake level during milk-feeding período and protein content in the post-weaning diet on performance and body composition in growing lambs. Animal Science, v. 67, p.513-521, 1998b.

MATRAS, J.; BARTLE, S. J.; PRESTON, R. L. Nitrogen utilization in growing lambs: effects of grain (starch) and protein sources with various rates of ruminal degradation. Journal of Animal Science, v.69, p. 339-347, 1991.

McClURE, K. E.; SOLOMON, M. B.; PARRET, N. A.; VAN KEUREN, R. W. Growth and tissue accretion of lambs fed concentrate in drylot, grazed on alfafa or ryegrass at weaning, or after backgrounding on ryegrass. Journal of Animal Science, v.73, p. 3437-3444, 1995.

MENDES, C. Q.; PEREIRA, E. M.; SUSIN, I.; PIRES, A. V.; OLIVEIRA Jr., R.C. Efeito do uso de monensina em dietas com alto concentrado sobre o desempenho de cordeiros confinados (compact disc). In: INTERNATIONAL SYMPOSIUM OF UNDERGRADUATED RESEARCH, 8., Piracicaba, 2000. Anais. Piracicaba: FEALQ, 2000. 
MERCHEN, N. R. Digestion, absorption and excretion in ruminants. In: $\mathrm{CHURCH}, \mathrm{D}$. C. The ruminant animal. Englewood Cliffs: Waveland Press, 1988. cap.9, p172-201.

MONTEIRO, A. L. G.; GARCIA, C. A.; NERES, M. A.; SPERS, R. C.; PRADO, O. R. Efeito da substituição do milho pela polpa cítrica no desempenho e características das carcaças de cordeiros confinados (compact disc). In: REUNIÃO ANUAL DA SOCIEDADE BRASILEIRA DE ZOOTECNIA, 35., 1998, Botucatu. Anais. Botucatu: SBZ, 1998.

MORAIS, J. B. ; SUSIN, I; PIRES, A. V.; OLIVEIRA Jr.,R.C. Efeito do uso de diferentes níveis de concentrado em dietas com bagaço de cana-de-açúcar (Saccharum sp L.) hidrolisado sobre o desempenho de cordeiros confinados (compact disc). In: SIMPÓSIO DE INICIAÇÃO CIENTÍFICA DA USP, 7., Piracicaba, 1999. Anais. Piracicaba: FEALQ, 1999.

MULLIGAN, F. J.; CAFFREY, P. J.; RATH, M.; KENNY, M. J.; O'MARA, F. P. The effect of dietary protein content and hay intake level on the true and apparent digestibility of hay. Livestock Production Science, v.68, p.41-52, 2001.

MURPHY, T. A.; LOERCH, S. C.; McCLURE, K. E.; SOLOMON, M. B. Effects of grain or pasture finishing system on carcass composition and tissue accretion rates of lambs. Journal of Animal Science, v.72, p. 3138-3144, 1994.

MUWALLA, M.M.; HARB, M.Y.; CROSBY, T.F. Effects of lasalocid and protein levels on the performance of Awassi lambs. Small Ruminant Research, v.28, p.15-22, 1998.

NATIONAL RESEARCH COUNCIL. Nutrient requirements of sheep. 6. ed. Washington : National Academic Press, 1985a. 99p.

NATIONAL RESEARCH COUNCIL. Ruminant nitrogen usage. Washington : National Academic Press, 1985b. 138p. 
NOTTER, D. R.; KELLY, R. F.; McCLAUGHERTY, F. S. Effects of ewe breed and management on eficiency of lamb production. Journal of Animal Science, v.69, n.22, p.22-33, 1991.

ORSKOV, E. R. Protein nutrition in ruminants. 2. ed. San Diego: Academic Press, 1992. 175p.

OWENS, F. N.; GOETSCH, A. L. Ruminal fermentation. In: $\mathrm{CHURCH,} \mathrm{D.} \mathrm{C.} \mathrm{The}$ ruminant animal. Englewood Cliffs: Waveland Press, 1988. cap.8, p.145171.

OWENS, F. N.; ZINN, R. Protein metabolism of ruminant animals. In: $\mathrm{CHURCH}$, D. C. The Ruminant Animal. Englewood Cliffs: Waveland Press, 1988. cap.12, p.227-249.

PALMQUIST, D.L.; CONRAD, H. Origin of plasma fatty acids in lactating cows fed high fat diets. Journal of Dairy Science, v.74, p.3152, 1971.

PEREZ, J. R. O.; GARCIA, I. F. F.; SILVA, R. H.; TEIXEIRA, J. C.; SANTOS, M. B. Desempenho de cordeiros Santa Inês e Bergamácia alimentados com diferentes níveis de dejetos de suínos. In: REUNIÃO ANUAL DA SOCIEDADE BRASILEIRA DE ZOOTECNIA, 35., Botucatu, 1998. Anais. Botucatu: SBZ, 1998. p.173-175.

PIRES, C. C.; ARAÚJO, J. R.; BERNARDES, R. A. C.; LANES, R. C.; JUNGES, E. R. V. Desempenho e características da carcaça de cordeiros de três grupos genéticos abatidos ao mesmo estágio de maturidade. Ciência Rural, v.29, n. 1, p.155-158, 1999.

PIRES, C. C.; SILVA, L.F.; SCHLICK, F. E.; GUERRA, D. P.; BISCAINO, G.; CARNEIRO, R. M. Cria e terminação de cordeiros confinados. Ciência Rural, v. 30, n. 5, p.875-880, 2000.

RIHANI, N.; GARRET, W. N.; ZINN, R. A. Influence of level of urea and method of supplementation on characteristics of digestion of high-fiber diets by sheep. Journal of Animal Science, v.71, n.6, p.1657-1665. 1993. 
ROGÉRIO, M. C. P.; BORGES, I.; TEIXEIRA, D. A. B.; RODRIGUES, N. M.; GONÇALVES, L. C.; BORGES, A. L. C. C.; SALIBA, E. O. S.; SILVA, A. G. $M$. Influência do consumo de proteína bruta e extrato etéreo dietéticos sobre as perdas de nitrogênio na urina e fezes de ovinos. In: REUNIÃO ANUAL DA SOCIEDADE BRASILEIRA DE ZOOTECNIA, 38., Piracicaba, 2001. Anais. Piracicaba: FEALQ, 2001. p.1121-1122.

SAS INSTITUTE. SAS user's guide: statistics; version 5. Cary, 1991.

SILVA, A. M. A.; SILVA SOBRINHO, A. G.; TRINDADE, I. A. C. M.; RESENDE, K. T. Exigências líquidas de proteína para ganho em ovinos lanados e deslanados. In: REUNIÃO ANUAL DA SOCIEDADE BRASILEIRA DE ZOOTECNIA, 38., Piracicaba, 2001. Anais. Piracicaba: FEALQ, 2001. p.1259-1261.

SILVA, J. F. C.; LEÃO, M. I. Fundamentos de nutrição de ruminantes. Piracicaba: Livroceres, 1979. 384p.

SILVA SOBRINHO, A.G. Composição corporal e exigências nutricionais de proteína para cabras em lactação. Revista Brasileira de Zootecnia, v.20, n.5, p.615-631, 1991.

SILVA SOBRINHO, A. G. Criação de ovinos. Jaboticabal : FUNEP, 1997. p.3974: Principais raças ovinas.

SILVA SOBRINHO, A. G. Aspectos quantitativos e qualitativos da produção de carne ovina. In: REUNIÃO ANUAL DA SOCIEDADE BRASILEIRA DE ZOOTECNIA, 38., Piracicaba, 2001. A produção animal na visão dos brasileiros. Piracicaba: FEALQ, 2001. p.425-453.

SILVA, R. H. Composição corporal e exigências de proteína e energia de cordeiros da raça Santa Inês. Lavras, 1999. 70p. Tese (Doutorado) Universidade Federal de Lavras.

SIQUEIRA, E. R.; FERNANDES, S. Pesos, rendimentos e perdas da carcaça de cordeiros Corriedale e mestiços Corriedale x lle de France, terminados em confinamento. Ciência Rural, v. 29, n. 1, p.143-148, 1999. 
SIQUEIRA, E. R. Sistemas de confinamento de ovinos para corte do sudeste do Brasil. In: SIMPÓSIO INTERNACIONAL SOBRE CAPRINOS E OVINOS DE CORTE, 1., João Pessoa, 2000. Anais. João Pessoa: EMEPA, 2000. p. 107118.

SNIFFEN, C. J.; BEVERLY, R. W.; MOONEY, C. S. Nutrient requirements versus suply in the dairy cow: strategies to account for variability. Journal of Dairy Science, v.73, n.10, p.3160-3178, 1993.

SOUSA, W. H. Ovinos Santa Inês: potencialidades e limitações. In: SIMPÓSIO NACIONAL DE MELHORAMENTO ANIMAL, 2., Uberaba, 1998. Anais. Viçosa: Sociedade Brasileira de Melhoramento Animal, 1998. p.233-237.

SOUZA, W. H.; MORAIS, O. R. Programa de melhoramento genético para ovinos deslanados do Brasil : ovinos da raça Santa Inês. In: SIMPÓSIO INTERNACIONAL SOBRE CAPRINOS E OVINOS DE CORTE, 1., João Pessoa, 2000. João Pessoa: EMEPA, 2000. p. 223-229.

STALLCUP, O. T.; DAVIS, G. V.; SHIELDS, L. Influence of dry matter and nitrogen intakes on fecal nitrogen losses in cattle. Journal of Dairy Science, v.58, n.9, p.1301-1307, 1975.

STERN, M. D.; VARGA, G. A., CLARK, J. H.; FIRKINS, J. L.; HUBER, J. T.; PALMQUIST, D. L. Evaluation of chemical and physical properties of feeds that affect protein metabolism in the rumen. Journal of Dairy Science, v.77, p.2762-2786, 1994.

SULTAN, J. I.; LOERCH, S. C. Effects of protein and energy supplementation of wheat straw- based diets on site of nutrient digestion and nitrogen metabolism of lambs. Journal of Animal Science, v.70, p. 2228-2234, 1992.

SUSIN, I. Confinamento de cordeiros. In: REUNIÃO ANUAL DA SOCIEDADE BRASILEIRA DE ZOOTECNIA, 38., Piracicaba, 2001. A produção animal na visão dos brasileiros. Piracicaba: FEALQ, 2001. p.454-460. 
SUSIN,I. ; ROCHA, M. H. M.; PIRES, A. V. Efeito do uso do bagaço de cana-deaçúcar in natura ou hidrolisado sobre o desempenho de cordeiros confinados (compact disc). In: REUNIÃO ANUAL DA SOCIEDADE BRAZILEIRA DE ZOOTECNIA, 37., Viçosa, 2000. Anais. Viçosa: SBZ, 2000.

SUSIN, I.; LOERCH, S. C.; McCLURE, K. E.; DAY, M. L. Effects of limit feeding a High-Grain diet on puberty and reproductive performance of ewes. Journal of Animal Science, v.73, p.3206-3215, 1995.

THÉRIEZ, M. The young lamb. In: $\mathrm{CHURCH,} \mathrm{D.} \mathrm{C.} \mathrm{Livestock} \mathrm{feeds} \mathrm{and}$ feeding. London: Prentice - Hall International, 1991. p.323-335.

THOMAS, V. M.; McINERNEY, M. J.; KOTT, R. W. Influence of body condition and lasalocid during late gestation on blood metabolites, lamb birth weight na colostrum composition and production in Finn-cross ewes. Journal of Animal Science, v.66, p. 783-791, 1988.

TITI, H.H.; TABBAA, M.J.; AMASHEH, M.G.; BARAKEH, F.; DAQAMSEH, B. Comparative performance of Awassi lambs and Black goat kids on different crude protein levels in Jordan. Small Ruminant Research, v.37, p.131-135, 2000.

TEIXEIRA, J. L. Minimização das perdas de nitrogênio em ovinos. In: SILVA SOBRINHO, A. G. Nutrição de ovinos. Jaboticabal: FUNEP, 1996. p81118.

TOURAINE, B. Influence des conditions d'elevage sur les caracteristics des carcasses et de la viande d'agneaux merinos d'Arles. Bulletin Technologie de'Elevage Ovin, v.4, p.29-33, 1984.

TRALDI, A. S. Manejo reprodutivo de caprinos e ovinos. / Apresentado à 11 . Semana Acadêmica da Faculdade de Medicina Veterinária da USP: Curso de Pequenos Ruminantes, Pirasununga, 2001/. 
VALADARES, R. F. D.; GONÇALVES, L. C.; SAMPAIO, I. B.; RODRIGUEZ, N. M.; SILVA, J. F. C. Níveis de proteína em dietas de bovinos. 2. Consumo, digestibilidade e balanço de compostos nitrogenados. Revista Brasileira de Zootecnia, v.26, n.6, p.1259-1263, 1997a.

VALADARES, R. F. D.; GONÇALVES, L. C.; SAMPAIO, I. B.; RODRIGUEZ, N. M.; VALADARES FILHO, S. C. Níveis de proteína em dietas de bovinos. 3. pH, amônia e eficiência microbiana. Revista Brasileira de Zootecnia, v.26, n.6, p.1264-1269, 1997b.

VAN SOEST, P. J.; ROBERTSON, J. B.; LEWIS, B. A. Methods for dietary fiber, neutral detergent fiber, and nonstarch polysaccharides in relation to animal nutrition. Journal of Dairy Science, v.74, p.3583, 1991.

VAN SOEST, P. J. Nutricional ecology of the ruminant. 2. ed. Ithaca: Cornell University Press, 1994. 476p.

VASCONCELOS, V.R.; LEITE, E.R.; BARROS, N.N. Terminação de caprinos e ovinos deslanados no Nordeste do Brasil. In: SIMPÓSIO INTERNACIONAL SOBRE CAPRINOS E OVINOS DE CORTE, 1., João Pessoa, 2000. João Pessoa: EMEPA, 2000. p. 97-107.

YOKOYAMA, M. T.; JOHNSON, K. A. Microbiology of the rúmen and intestine. In: $\mathrm{CHURCH}, \mathrm{D}$. C. The ruminant animal. Englewood Cliffs: Waveland Press, Inc., 1988. cap.8, p.145-171.

ZEOULA, L. M.; PRADO, I. N.; CECATO, U. Valor Nutritivo de rações compostas de fonte de amido e de nitrogênio com alta e baixa degradabilidade ruminal. Revista Brasileira de Zootecnia, v.28, n.5, p.1159-1167, 1999.

ZUNDT, M.; MACEDO, F. A. F.; MARTINS, E. L.; MEXIA, A. A.; YAMAMNOTO, S. M. Desempenho de cordeiros alimentados com diferentes níveis de proteína. In: REUNIÃO ANUAL DA SOCIEDADE BRASILEIRA DE ZOOTECNIA, 38., Piracicaba, 2001. Anais. Piracicaba: FEALQ, 2001a. p.985-987. 
ZUNDT, M.; MACEDO, F. A. F.; MARTINS, E. L.; MEXIA, A. A.; MARTIN NIETO, L.; YAMAMNOTO, S. M. Características de carcaça de cordeiros terminados em confinamento, alimentados com diferentes níveis protéicos. In: REUNIÃO ANUAL DA SOCIEDADE BRASILEIRA DE ZOOTECNIA, 38., Piracicaba, 2001. Anais. Piracicaba: FEALQ, 2001b. p.988-990.

ZUNDT, M.; MACEDO, F. A. F.; MEXIA, A. A.; CALDAS NETO, S. F.; YAMAMNOTO, S. M; MACEDO, L. G. Digestibilidade total aparente in vivo de dietas contendo diferentes níveis protéicos em ovinos. In: REUNIÃO ANUAL DA SOCIEDADE BRASILEIRA DE ZOOTECNIA, 38., Piracicaba, 2001. Anais. Piracicaba: FEALQ, 2001c. p.1339-1340. 